NBER WORKING PAPER SERIES

\title{
THE GREAT DEPRESSION AS A WATERSHED: INTERNATIONAL CAPITAL MOBILITY OVER THE LONG RUN
}

Maurice Obstfeld

Alan M. Taylor

Working Paper 5960

\author{
NATIONAL BUREAU OF ECONOMIC RESEARCH \\ 1050 Massachusetts Avenue \\ Cambridge, MA 02138 \\ March 1997
}

Paper presented at an NBER conference held at Kiawah Island, SC, October 1996, and forthcoming in the conference volume The Defining Moment: The American Economy in the Twentieth Century edited by Michael D. Bordo, Claudia Goldin, and Eugene N. White (Chicago: University of Chicago Press, 1997). We are grateful to Haru Connolly, Matthew Jones, and Ryan Edwards for superb assistance and to Lance Davis and Pierre Sicsic for helpful discussions. Special debts are owed to Barry Eichengreen for numerous suggestions and references and to Michael Bordo for extensive comments on several drafts. Financial support was provided by the National Science Foundation and by the Center for German and European Studies at UC Berkeley. This paper is part of NBER's research programs in the Development of the American Economy, International Finance Macroeconomics and International Trade and Investment. Any opinions expressed are those of the authors and not those of the National Bureau of Economic Research.

(C) 1997 by Maurice Obstfeld and Alan M. Taylor. All rights reserved. Short sections of text, not to exceed two paragraphs, may be quoted without explicit permission provided that full credit, including $(\mathcal{C})$ notice, is given to the source. 
The Great Depression as a Watershed: International

Capital Mobility over the Long Run

Maurice Obstfeld and Alan M. Taylor

NBER Working Paper No. 5960

March 1997

JEL Nos. F33, N20

Development of the American Economy,

International Finance and Macroeconomics

and International Trade and Investment

\section{ABSTRACT}

This paper surveys the evolution of international capital mobility since the late nineteenth century. We begin with an overview of empirical evidence on the fall and rise of integration in the global capital market. A discussion of institutional developments focuses on the use of capital controls and the pursuit of domestic macroeconomic policy objectives in the context of changing monetary regimes. A fundamental macroeconomic policy trilemma has forced policymakers to trade off among conflicting goals. The natural implication of the trilemma is that capital mobility has prevailed and expanded under circumstances of widespread political support either for an exchangerate subordinated monetary policy regime (e.g., the gold standard), or for a monetary regime geared mainly toward domestic objectives at the expense of exchange-rate stability (e.g., the recent float). Through its effect on popular attitudes toward both the gold standard and the legitimate scope for government macroeconomic intervention, the Great Depression emerges as the key turning point in the recent history of international capital markets.

Maurice Obstfeld

Department of Economics

549 Evans Hall

University of California, Berkeley

Berkeley, CA 94720-3880

and NBER

obstfeld@econ.berkeley.edu
Alan M. Taylor

Department of Economics

Northwestern University

2003 Sheridan Road

Evanston, IL 60208-2600

and NBER

amt.nwu.edu 
The era of the classical gold standard, circa 1870 to 1914 , is rightly regarded as a high-water mark in the free movement of capital, labor, and commodities among nations. After World War I, the attempt to rebuild a world economy along pre-1914 lines was swallowed up in the Great Depression and in the new world war that the Depression bred. Only in the 1990s has the world economy achieved a degree of economic integration that, in the assessment of Sachs and Warner (1995), rivals the coherence already attained a century earlier. This development broadly fulfills the hopes for the world economy that United States policymakers held at the close of World War II, albeit within an institutional and policy context far different from the one they designed or even envisioned.

Why did the network of world trade suddenly collapse in the Depression, and how did the collapse itself influence the subsequent process of regeneration? This chapter is primarily concerned with one aspect of international commerce, capital movements, although the forces restraining international capital movements are not fully understandable without an appreciation of the natures and purposes of related restraints on other kinds of trade.

In the present chapter we document empirically the ebb and flow of international capital mobility over more than a hundred years and propose a simple framework for interpreting the economic forces that gave rise both to the disintegrative trend initiated by the Depression and to the boom in global capital mobility of recent years. After first reviewing briefly the economic functions of international capital movements, we review some cmpirical evidence. Our quantitative indicators-- and a wider literature - are in broad agreement that international capital mobility was considerable during the classical gold standard and under the reconstituted gold standard through around 1930. They likewise agree that mobility contracted sharply as a result of the Depression and World War II, and then slowly reemerged, albeit with significant reversals, starting in the late 1950s.

With the quantitative history laid out for interpretation, we next chronicle the major vicissitudes of the international capital market starting with World War I. Financial controls deployed in the course of all-out war were relaxed later during an interregnum of floating exchange rates that was widely viewed as a prelude to the "normalcy" of a restored gold standard. Nearly universal (again) by the end of the 1920s, the gold standard was shattered by the Great Depression. Many countries utilized controls of some sort in their 
attempts to maintain gold parities and international finance became fragmented as even free-exchange countries struck bilateral deals with Germany and other exchange-controllers. Controls spread and intensified in World War II. Bilateral trade arrangements proliferated after the war in a scramble to husband scarce hard-currency-mostly U.S. dollar-resources.

The gradual restoration of convertibility in Europe (and elsewhere), fostered in part by American Marshall aid and the European Payments Union, promoted growing world trade and, with it, a growing risk of pressures on the pegged exchange rates mandated by the postwar Bretton Woods system. The breakdown of fixed dollar rates in the early 1970s led, in turn, to extensive liberalization of capital movements by the United States and Germany starting in 1974, by Japan starting in 1979, and by Britain in the same year. Most of Europe, and much of the developing world, followed suit starting around 1990. Evidently, individual country experiences have differed, as have the motivations for external liberalization and the institutional setting in which it has taken place. These differences notwithstanding, financial openness has now reached a depth, universality, and resiliency comparable to that of the classical gold standard era. But that development was consummated only in the 1990s.

Secular movements in the scope for international lending and borrowing may be understood, we shall argue, in terms of a fundamental macroeconomic policy trilemma that all national policymakers face: the chosen macroeconomic policy regime can include at most two elements of the "inconsistent trinity" of (i) full freedom of cross-border capital movements, (ii) a fixed exchange rate, and (iii) an independent monetary policy oriented toward domestic objectives. If capital movements are prohibited (element [i] is ruled out), a country on a fixed exchange rate can break ranks with foreign interest rates and thereby run an independent monetary policy. Similarly a floating exchange rate (element [ii] is ruled out) reconciles freedom of international capital movements with monetary-policy effectiveness (at least when some nominal domestic prices are sticky). But monetary policy is powerless to achieve domestic goals when the exchange rate is fixed and capital movements free (element [iii] is ruled out), since intervention in support of the exchange parity then entails capital flows that exactly offset any monetarypolicy action threatening to alter domestic interest rates.

Recognition of the policy trilemma leads to a central proposition of this 
paper. Capital mobility has prevailed and expanded under circumstances of widespread political support either for an exchange-rate subordinated monetary policy regime (e.g., the gold standard), or for a monetary regime geared mainly toward domestic objectives at the expense of exchange-rate stability (e.g., the recent float). The middle ground in which countries attempt simultaneously to hit exchange-rate targets and domestic policy goals has, almost as a logical consequence, entailed exchange controls or other harsh constraints on international transactions. ${ }^{1}$

The Great Depression stands as a watershed in that it was caused by an ill-advised subordination of monetary policy to an exchange-rate constraint (the gold standard), which led to a chaotic time of troubles in which countries experimented, typically noncooperatively, with alternative modes of addressing the fundamental policy trilemma. Interwar experience, in turn, discredited the gold standard and led to a new and fairly universal policy consensus, one that shaped the more cooperative postwar international economic order fashioned by Harry Dexter White and John Maynard Keynes, but also implanted within that order the seeds of its own eventual destruction a quarter-century later. The global financial nexus that since evolved is based on a solution to the basic open-economy trilemma quite different than that envisioned by Keynes or White---one that allows considerable freedom for capital movements, gives the major currency areas freedom to pursue internal goals, but largely leaves their mutual exchange rates as the equilibrating residual.

\section{Capital Mobility: Implications and Historical Evidence}

This section discusses the ramifications of capital mobility in the international economy and reviews the current evidence we have as to the rise and fall of capital mobility over the long run. Section 1.1 discusses the functional importance of capital mobility in historical perspective, touching on issues of economic efficiency and the long-run convergence process. Section 1.2 documents some basic evidence on the evolution of the global capital market, namely the extent of capital flows, as measured by countries' balances on current account, equal to net foreign investment. Then section 1.3 exam- 
ines the evolution of nominal interest differentials as a guide to the extent of market integration. Section 1.4 looks at international differences in real domestic interest rates, taken as measures of the required return to capital. Along the way we draw on related literature devoted to more sophisticated econometric tests of market integration, but all evidence points to the interwar period, and especially the Great Depression, as the era of weakest financial integration: capital flows were small, countries behaved like closed economies in the capital market, and real and nominal price (interest rate) differentials expanded.

\subsection{Functions of Capital Mobility}

We think it important to highlight the functions of capital mobility both for efficiency and for policy. The efficiency implications are clear enough: when capital is immobile, it may not be free to seek out the highest return within the global economy. Nor can countries smooth temporary fluctuations in consumption through international borrowing and lending, or diversify risks through the exchange of assets with uncertain and imperfectly correlated payoffs. From the 1930s investors had good reason to be cautious of committing funds to foreign countries which had (or might enact) forms of capital control, since returns might be compromised by controls intended to tax or prevent the repatriation of profits. Cumulating over many years or decades, such disincentives could tend to produce a global misallocation of capital, with an inefficient and excessive amount of capital remaining in capital-abundant (rich) countries, and too little flowing to capital-scarce (poor) counties (Lucas 1990). Domestic savings could be biased toward use in domestic investment activity (Feldstein and Horioka 1980). These tendencies do indeed seem to be characteristic of much of the postwar period, as the evidence below suggests.

Such an outcome was not discouraged by the tolerant and benign view of capital controls which prevailed for several decades in the aftermath of the Great Depression.

Such an historical process would naturally have implications for the crosscountry patterns of economic growth and development: to the extent that an excess of capital remained in capital-rich countries the process of convergence could have been retarded. Beyond just the evolution of productivity levels, such capital misallocation would have distributional implications. In- 
efficiently allocated capital would be earning low returns in capital-abundant locales, and capital-scarce areas would be characterized by inefficiently low wages. Furthermore, the process of capital market integration would be tied to factor-price equalization via trade and integration in goods markets (absent large scale labor migration in the late twentieth century), an historical process deservedly attracting new attention (Wood 1994; Williamson 1996).

Another potential function of an open capital market under conditions of high capital mobility is as a disciplining device on policymakers. Unsound policies may be limited by the threat of massive capital outflow. This form of commitment mechanism might be seen as supplementing, or possibly even dominating, any disciplinary power inherent in a commitment to an exchange rate peg. The full set of gold standard "rules of the game" has been characterized as a form of commitment mechanism or reputational device because of the explicit constraints on monetary policy, and implicit constraints on fiscal policy (Bordo and Kydland 1995; Bordo and Rockoff 1996).

These advantages of international capital mobility have all motivated its growth after periods of full or partial capital-market collapse. As in the case of conventional commodity trade, however, the process of market reintegration itself has required and reflected a political context enabling countries to overcome the coordination problems that often can obstruct the gains from trade.

\subsection{Trends in Current Accounts}

Following Eichengreen (1992a) and Taylor (1996b), we turn to some basic measures of the extent of capital flows throughout the past century. A sense of the changing patterns of international financial flows can be gleaned by examining their trends and cycles.

We focus on the size of the current account balance $C A$ as a fraction of national income $Y$. Thus $(C A / Y)_{i t}$ becomes the variable of interest, for country $i$ in period $t$. By dint of the national income identity, the current account equals the difference between national saving $S$ and domestic investment $I$,

$$
C A=S-I,
$$

and thus corresponds to net foreign investment, or, alternatively, to the level of net capital outflow. Thus the size of the current account measures the 
extent to which the economy is borrowing abroad to finance its investment $(C A<0)$ or is lending abroad to facilitate foreign investment in excess of foreign saving $(C A>0) .^{2}$

Table 2.1 and Figure 2.1 present the basic trends in foreign capital flows. ${ }^{3}$ To measure the extent of capital flows we use the mean absolute value $\mu_{|C A / Y|, t}$ in each cross section at time $t$. Quinquennially averaged data are used in the figure, and in the table we present data for selected periods. By this measure, the average size of capital flows in our sample was often as high as $4 \%-5 \%$ of national income before World War I. ${ }^{4}$ At its first peak it reached $5.1 \%$ in the overseas investment boom of the late $1880 \mathrm{~s}$. This dropped back to around $3 \%$ in the depression of the 1890s. The figure approached $4 \%$ again in the years 1910 to 1914 , and wartime lending pushed the figure over $5 \%$ in the years 1915 to 1919 . Flows diminished in size in the 1920 s, however, and international capital flows were less than $1.5 \%$ of national income in the late 1930s. Again, wartime loans raised the figure in the 1940s, but in the 1950s and $1960 \mathrm{~s}$, the size of international capital flows in this sample reached an all time low, around $1 \%$ of national income. Only in the late 1970s and 1980s have flows increased, though not to levels above those of a century ago.

These basic descriptive data do illustrate the record of capital flows, and offer prima facie evidence that the globalization of the capital market has been subject to major dislocations, most notably over the interwar period, with a dramatic contraction of flows seen in the Depression of the 1930s. Moreover, this low level in the volume of flows persisted long into the postwar era. More sophisticated analysis of the quantity (flow) data is, of course, possible. The current-account identity may be examined through a study of the relationship between domestic saving and investment, following Feldstein and Horioka (1980). Applying such techniques to 150 years of panel data as described above strengthens the basic impression that capital mobility reached its low point in the 1930s (Eichengreen 1992a; Obstfeld 1995; Taylor 1996b).

\subsection{Evidence on Nominal Interest Rates}

Perhaps the most unambiguous indicator of capital mobility is the relationship between interest rates on identical assets located in different financial centers (see the discussion in Obstfeld 1995, for example). Thus, for ex- 
Table 2.1

The Extent of Capital Flows Since 1870

Mean Absolute Value of Current Account, 12 Countries, Selected Periods, Percent of GDP

\begin{tabular}{lrrrrrrrrrrrrr} 
& ARG & AUS & CAN & DNK & FRA & DEU & ITA & JPN & NOR & SWE & GBR & USA & All \\
\hline $1870-1889$ & 18.7 & 8.2 & 7.0 & 1.9 & 2.4 & 1.7 & 1.2 & 0.6 & 1.6 & 3.2 & 4.6 & 0.7 & 3.7 \\
$1890-1913$ & 6.2 & 4.1 & 7.0 & 2.9 & 1.3 & 1.5 & 1.8 & 2.4 & 4.2 & 2.3 & 4.6 & 1.0 & 3.3 \\
$1914-1918$ & 2.7 & 3.4 & 3.6 & 5.1 & - & - & 11.6 & 6.8 & 3.8 & 6.5 & 3.1 & 4.1 & $(5.1)$ \\
$1919-1926$ & 4.9 & 4.2 & 2.5 & 1.2 & 2.8 & 2.4 & 4.2 & 2.1 & 4.9 & 2.0 & 2.7 & 1.7 & 3.1 \\
$1927-1931$ & 3.7 & 5.9 & 2.7 & 0.7 & 1.4 & 2.0 & 1.5 & 0.6 & 2.0 & 1.8 & 1.9 & 0.7 & 2.1 \\
$1932-1939$ & 1.6 & 1.7 & 2.6 & 0.8 & 1.0 & 0.6 & 0.7 & 1.0 & 1.1 & 1.5 & 1.1 & 0.4 & 1.2 \\
$1940-1946$ & 4.8 & 3.5 & 3.3 & 2.3 & - & - & 3.4 & 1.0 & 4.9 & 2.0 & 7.2 & 1.1 & $(3.2)$ \\
$1947-1959$ & 2.3 & 3.4 & 2.3 & 1.4 & 1.5 & 2.0 & 1.4 & 1.3 & 3.1 & 1.1 & 1.2 & 0.6 & 1.8 \\
$1960-1973$ & 1.0 & 2.3 & 1.2 & 1.9 & 0.6 & 1.0 & 2.1 & 1.0 & 2.4 & 0.7 & 0.8 & 0.5 & 1.3 \\
$1974-1989$ & 1.9 & 3.6 & 1.7 & 3.2 & 0.8 & 2.1 & 1.3 & 1.8 & 5.2 & 1.5 & 1.5 & 1.4 & 2.2 \\
$1989-1996$ & 2.0 & 4.5 & 4.0 & 1.8 & 0.7 & 2.7 & 1.6 & 2.1 & 2.9 & 2.0 & 2.6 & 1.2 & 2.3 \\
\hline
\end{tabular}

Notes: Annual data. See text. Parentheses denote average with some countries missing.

Sources: See Taylor (1996a). Some estimates revised.

Figure 2.1

The Extent of Capital Flows Since 1870

Mean Absolute Value of Current Account, 12 Countries, Quinquennia, Percent of GDP

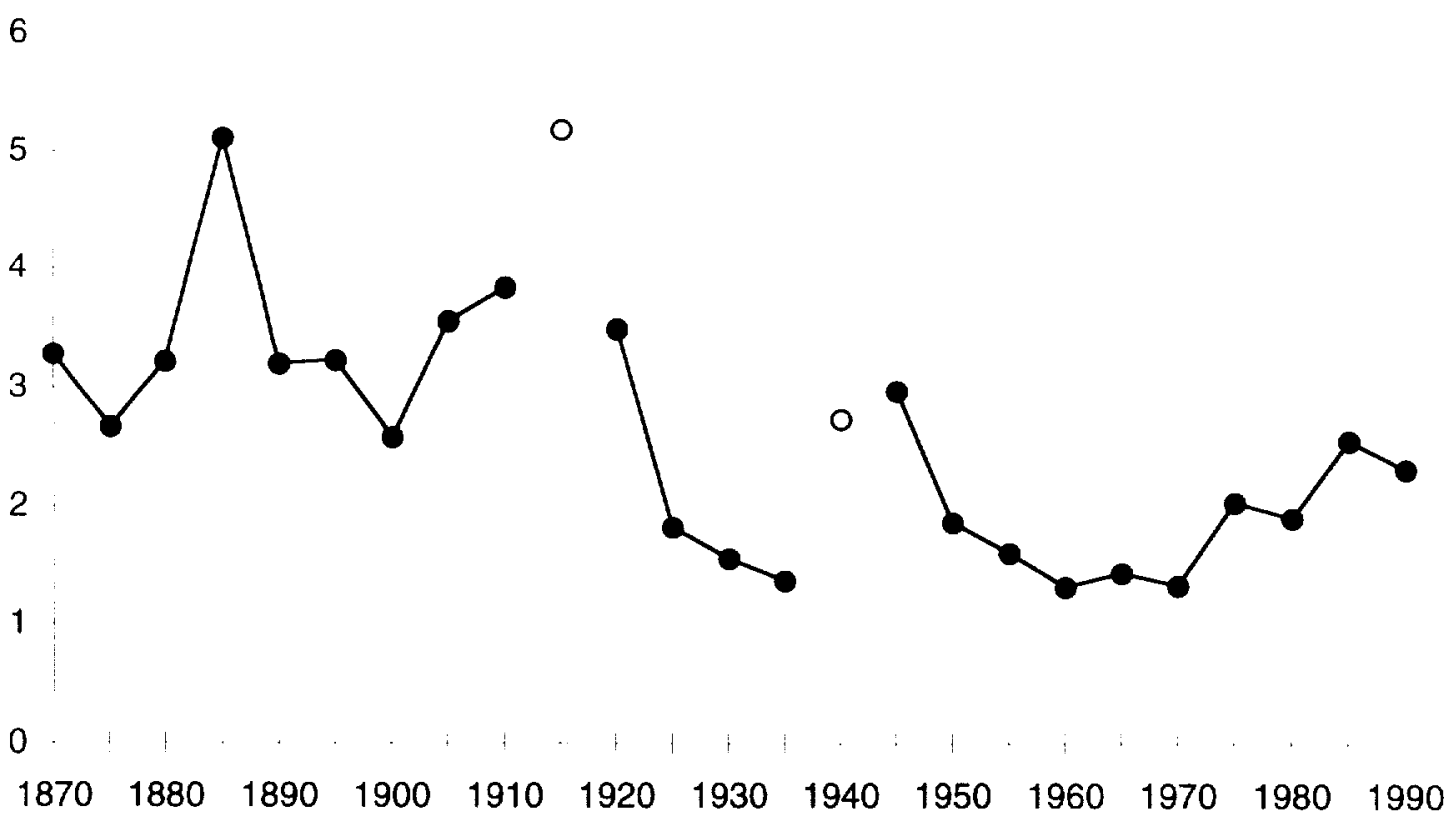

Notes and Sources: See Table 2.1. Open circles denote wartime samples. 
ample, interest rates on Euromark deposits in London in recent years have been quite close to those on comparable Deutsche mark deposits in Bonn. The great advantage of comparing onshore and offshore interest rates such as these is that relative rates of return are not affected by pure currency risk. ${ }^{5}$

For much of the period we study in this paper, a direct onshore-offshore comparison is impossible. However, the existence of forward exchange instruments allows us to construct roughly equivalent measures of the return to currency-risk-free international arbitrage operations. Forward exchange trading - in which two parties contract to exchange currencies at a predetermined rate on an agreed date- is one way to conduct international interestrate arbitrage free of currency risk. Using monthly data on forward exchange rates, spot rates, and nominal interest rates for 1921 to 1996, we assess the degree of international financial-market integration by calculating the return to covered interest arbitrage between financial centers. For example, a London resident could earn the gross sterling interest rate $1+i_{t}^{*}$ on a London loan of one pound sterling. Alternatively, he could invest the same currency unit in New York, simultaneously covering his exchange risk by selling dollars forward. He would do this in three steps: Buy $e_{t}$ dollars in the spot exchange market (where $e_{t}$ is the spot price of sterling in dollar terms); next, invest the proceeds for a total of $e_{t}\left(1+i_{t}\right)$ (where $i_{t}$ is the nominal dollar interest rate; and, finally, sell that sum of dollars forward at for $e_{t}\left(1+i_{t}\right) / f_{t}$ in sterling (where $f_{t}$, the forward exchange rate, is the price of forward sterling in terms of forward dollars). The net gain from borrowing in London and investing in New York,

$$
\frac{e_{t}}{f_{t}}\left(1+i_{t}\right)-\left(1+i_{t}^{*}\right)
$$

is zero when capital mobility is perfect and the interest rates and forward rate are free of default risk.

We can pursue a similar arbitrage calculation before 1920 , but with minor modifications to correspond to historical practice and the prevailing financial instruments and institutions of that earlier time. Forward exchange markets functioned before World War I (Einzig 1937, chap. 7), but they were comparatively thin before the suspension of the gold standard that followed the war. For the period 1870 through 1920, we consider a different type of sterling interest-rate arbitrage operation between London and New York, the dominant market of its kind, going through the New York market for sixty-day sterling bills (for a discussion of this market, see Perkins 1978). Sixty-day 
sterling bills were promises to pay the bearer one pound sterling, usually in London, after sixty days. Thus, the dollar price of a sterling bill is the New York price of forward sterling in terms of current dollars. Rather than lending a pound in London at the gross interest rate prevailing there, one could instead buy $e_{t}$ sight dollars and use these to purchase $e_{t} / b_{t}$ pounds payable in sixty days (where $b_{t}$ is the New York dollar price of a sterling bill). The net gain from borrowing in London to buy sterling bills in New York would be

$$
\frac{e_{t}}{b_{t}}-\left(1+i_{t}^{*}\right)
$$

which again is zero under perfect financial integration of the New York and London markets. ${ }^{6}$

Table 2.2 and Figure 2.2 present some evidence on covered interest arbitrage on the dollar-sterling exchange since 1870, showing the above differentials for the years 1870 to 1939 and 1947 to the present. Differential returns are calculated as annual rates of accrual. Some concerns about the data warrant mention. ${ }^{7}$ First, as described above, the two measures of market integration that we calculate refer to different arbitrage possibilities before and after 1920, and thus comparability across this break cannot be assured. Second, the forward and sterling bill transactions appear at different maturities in our data set: before 1920 we deal with two-month rates, afterward with three-month rates. Third, most data are observed at or near end-of-month, but all data for the years from 1921 to 1936 are averages of weekly numbers. Averaging has the effect of dampening measured volatility for part of the interwar period. Fourth, data from World War II reflect rigidly administered prices and have no capital-mobility implications. Fifth, the data used are not closely aligned for time of day (and even differ as to day in some cases), so that some of the monthly deviations from nominal interest parity that we calculate may be spurious. Sixth and finally, this exercise is being performed here only for a single country-pair, the United States and United Kingdom. In future work we hope to compile similar data for more countries, including France and Germany, to permit an evaluation of covered interest arbitrage between other markets.

Despite these many caveats, the figures are revealing and supportive of the conventional wisdom. Differentials are relatively small and steady under the pre-1914 gold standard, but start to open up during World War I. They stay quite large in the early 1920 s. $^{8}$ Differentials diminish briefly in the late 
Table 2.2

Nominal Interest Parity Since $\mathbf{1 8 7 0}$

U.S.-U.K. Covered Domestic Interest Differentials, Selected Periods, Percent per Annum

\begin{tabular}{lrr} 
& mean & s.d. \\
\hline $1870-1889$ & 1.02 & 0.66 \\
$1890-1913$ & 0.60 & 0.39 \\
$1914-1918$ & 0.05 & 0.70 \\
$1919-1924$ & 1.05 & 2.06 \\
$1925-1930$ & -0.58 & 0.95 \\
$1931-1939$ & 0.12 & 2.05 \\
$1940-1946$ & -0.44 & 0.31 \\
$1947-1956$ & 0.35 & 1.10 \\
$1957-1967$ & -0.01 & 0.67 \\
$1968-1979$ & 0.10 & 2.01 \\
$1980-1989$ & -0.64 & 1.28 \\
$1990-1996$ & 0.25 & 0.47 \\
\hline
\end{tabular}

Notes: Monthly data. Various maturities. Sixty-day bills before 1920, forward exchange after 1920 . Sources: Various. See text.

Figure 2.2

Nominal Interest Parity Since $\mathbf{1 8 7 0}$

U.S.-U.K. Covered Domestic Interest Differentials, Annual, Percent per Annum

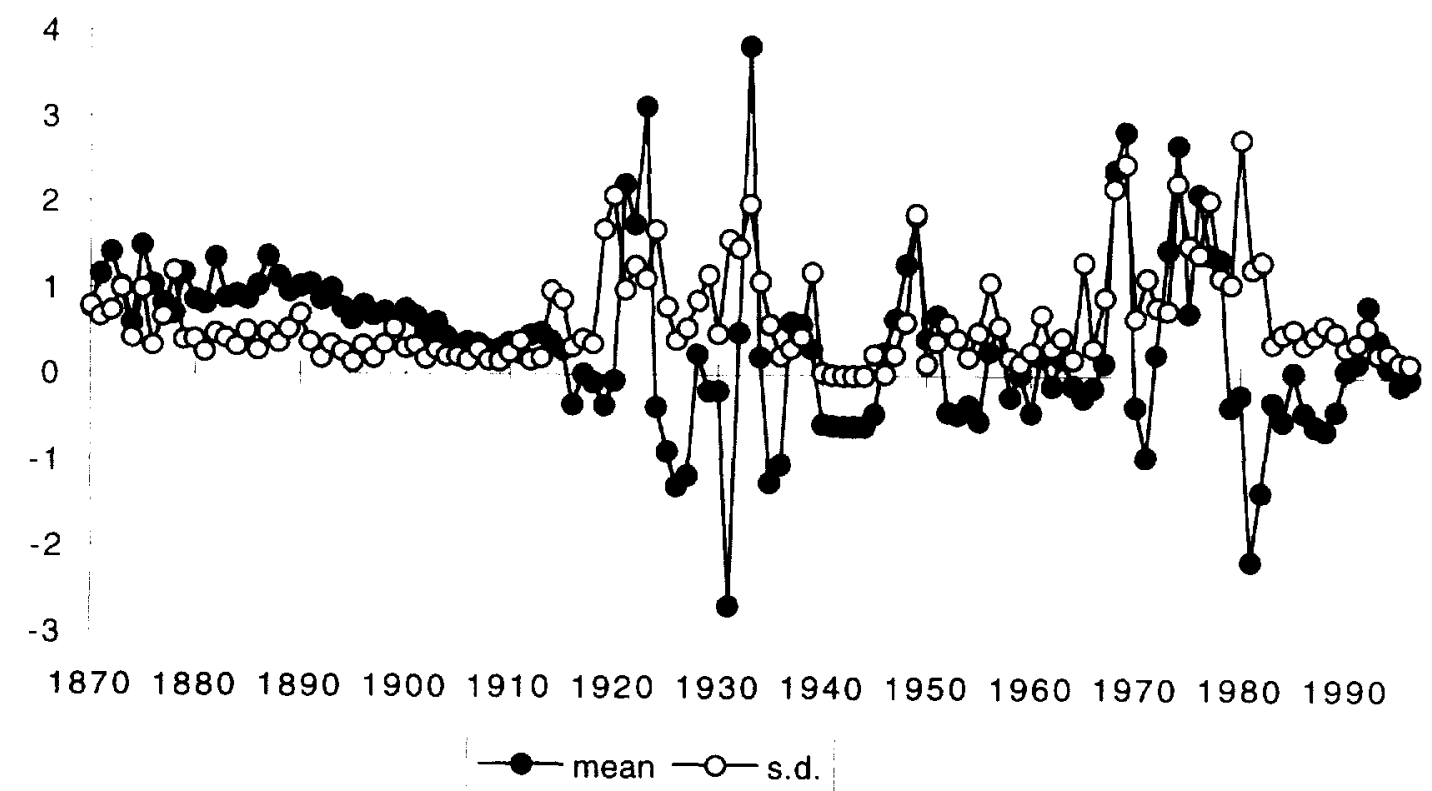

Notes and Sources: See Table 2.2. 
1920 s, but widen sharply in the early 1930s. There are some big arbitrage gaps in the late 1940s through the mid-1950s, but these shrink starting in the late 1950s and early 1960s, only to open up again in the late 1960s as sterling is devalued and as the Bretton Woods system unravels in the early 1970s. Interest differentials have become small once again only in the most recent years of floating exchange rates. Thus, the Great Depression, perhaps as part of a much broader interwar phase of disintegration, stands out as an event that transformed the world capital market and left interest arbitrage differentials higher and more volatile than ever before. Disintegration lasted for several decades, and large nominal return differentials persisted into the $1980 \mathrm{~s}$.

\subsection{Evidence on Real Interest Rates}

A basic standard for market integration remains the law of one price. This is usually interpreted for capital markets as implying some test for the equalization of real costs of capital, typically real interest rates. It is well known, however, that real interest rate convergence is a very strong criterion for market integration, resting as it does not only on perfect capital mobility but also on two supplementary parity relationships, either of which may fail to hold and which are not directly relevant to capital mobility: uncovered interest parity (UIP) and purchasing power parity (PPP). ${ }^{9}$

Clearly, risk premia can modify UIP even in a world of free trade and frictionless asset markets, so UIP cannot be a relevant precondition for free capital mobility. As is well known, however, it is hard to devise reasonable models in which currency risk premia are large (Lewis 1996). As for PPP it may fail even over the long run because nontraded goods enter consumption price indexes. If capital is mobile and technologies ultimately converge internationally, however, there will be a tendency for countries' relative prices of nontradables in terms of tradables to be equalized as time passes. The mechanism bringing about this equality is akin to that underlying the factorprice equalization proposition in trade theory (see Obstfeld and Rogoff 1996, chap. 4). It can work even without capital mobility, of course, but is likely to be speeded by the technology transfer that international capital mobility may facilitate. ${ }^{10}$ Thus, even though PPP is sometimes asserted to be a proposition about goods-market integration, capital mobility can indeed be 
relevant to the issue, hence to the international equality of expected real interest rates. Studies of long-run patterns of PPP may be very suggestive of the likely periods in which real interest parity holds or fails. Taylor (1996a) works with a 20-country panel data set and shows that the interwar period, and especially the 1930s, represent times of marked deviation from PPP in the cross-section. In contrast, the recent float shows evidence of a return to relatively tight PPP conditions not seen since the classical gold standard of the late nineteenth century. These findings beg the question whether real interest parities show similar patterns of historical evolution, as one might expect.

The real-interest parity relationship between prices in two physically separate, but economically integrated, markets could be tested in a number of ways. Prices may be equalized save for some transaction-cost gap; or they may equalize in the long-run, but exhibit short-run deviations. Such concerns make the test of strict and permanent equality only the most extreme or strict criterion for integration. If integration is not viewed as a zero-one variable, the degree of integration becomes a valid object of research. Exploring both the equilibrating forces of adjustment (promoting convergence in prices) and the nature of disequilibrating shocks to the system (promoting divergence), we may ask: how did the system perform in terms of the overall deviations from real interest rate equality which were actually recorded across time? The dispersion of the real interest rate is of interest because it does indeed summarize two facets of the capital market: the size of market-specific shocks (impulses) and the capacity of the system to smooth out these shocks across space (propagation). The two together describe the stability and unity of the global capital market. Naturally a system with uniform price shocks across regions will never be put to the test in terms of its adjustment capacity; and a system with good adjustment dynamics could cope with pronounced local disturbances and still dissipate the shocks so as to equalize rates of return quickly.

The patterns of real interest rate dispersion offer preliminary evidence as to the working efficiency and stability of the world capital market, and the basic record for our sample of countries is indicated by Table 2.3 and Figure 2.3. Shown there is the standard deviation of real ex post interest rates for a sample of ten countries from 1880 to 1989 . Quinquennially averaged data are used in the figure, and in the table we present data for selected periods. ${ }^{11}$ 
Table 2.3

Real Interest Parity Since 1870

Dispersion of Real Interest Rate, 10 Countries, Selected Periods, Percent per Annum

\begin{tabular}{|c|c|c|c|c|c|c|c|c|c|c|}
\hline & \multicolumn{9}{|c|}{ Average absolute differential relative to USA } & \multirow{2}{*}{$\begin{array}{c}\text { All countries } \\
\text { Standard deviation }\end{array}$} \\
\hline & AUS & BEL & CAN & FRA & DEU & ITA & NLD & SWE & GBR & \\
\hline $1870-1889$ & 4.5 & 3.8 & 4.3 & 4.8 & 1.6 & 1.8 & 3.3 & 3.2 & 3.3 & 4.2 \\
\hline $1890-1913$ & 2.8 & 4.1 & 2.1 & 4.2 & 2.4 & 1.8 & 2.8 & 2.6 & 1.8 & 3.4 \\
\hline 1914-1918 & 7.9 & - & 1.3 & - & 0.7 & 11.0 & 5.8 & 8.3 & 6.2 & (9.1) \\
\hline 1919-1926 & 3.5 & 34.1 & 2.2 & 13.5 & 6.1 & 9.4 & 4.2 & 5.8 & 4.6 & 20.2 \\
\hline 1927-1931 & 2.9 & 7.6 & 1.1 & 6.6 & 2.9 & 4.8 & 1.7 & 1.8 & 1.3 & 6.0 \\
\hline $1932-1939$ & 3.3 & 3.3 & 1.2 & 10.7 & 2.6 & 4.7 & 3.8 & 3.4 & 3.0 & 6.5 \\
\hline 1940-1946 & 3.3 & 10.7 & 3.2 & - & - & 38.5 & 5.5 & 5.2 & 3.9 & (22.3) \\
\hline $1947-1959$ & 4.4 & 3.3 & 1.8 & 4.5 & 4.5 & 4.4 & 4.2 & 3.0 & 2.1 & 6.0 \\
\hline 1960-1973 & 1.3 & 1.3 & 1.0 & 0.9 & 1.8 & 2.0 & 1.7 & 1.4 & 1.3 & 1.6 \\
\hline $1974-1989$ & 1.9 & 2.4 & 1.2 & 1.5 & 2.4 & 2.2 & 2.3 & 1.8 & 3.2 & 3.7 \\
\hline $1989-1996$ & 3.3 & 2.4 & 2.0 & 2.3 & 1.3 & 2.6 & 1.8 & 1.8 & 1.5 & 1.7 \\
\hline
\end{tabular}

Notes: Annual data. See text. Parentheses denote average with some countries missing.

Sources: Unpublished data from Michael Bordo, with some series extended.

Figure 2.3

Real Interest Parity Since 1870

Dispersion of Real Interest Rate, 10 Countries, Quinquennia, Percent per Annum

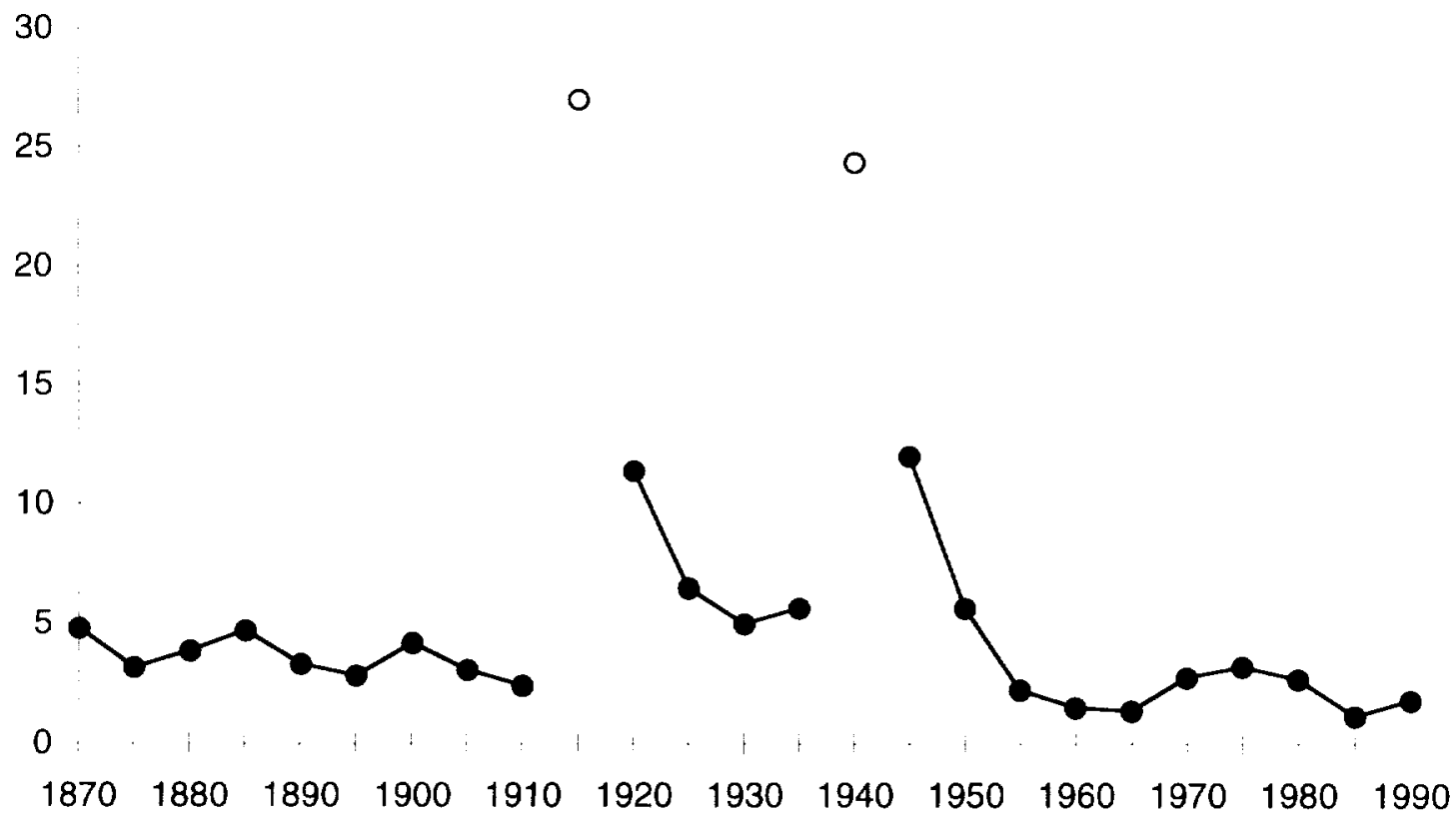

Notes and Sources: See Table 2.3. Open circles denote wartime samples. 
The dispersion measure (the standard deviation) of real rates shows a pattern definite pattern. There was slight convergence in real interest rates after 1880 and before 1914, though nothing as dramatic as the convergence seen prior to 1880 (cf. Lothian 1995). But after 1914, the dispersion of real rates almost doubled. It fell slightly from the late 1920s to the early 1930s, but then increased again. Dispersion hit a peak in the late 1940s, and then convergence in real interest rates was again seen during the early phase of Bretton Woods, such that, after 1960, dispersion levels had returned to their pre-1914 levels. Dispersion has been flat almost ever since, with some divergence apparent upon the collapse of the Bretton Woods system in the early 1970 s.

The dispersion data thus confirm again the textbook characterization of the evolution of international capital market integration. Integration was relatively high in the late nineteenth and late twentieth centuries--though arguably no better now than under the gold standard - and it was subject to a massive dislocation in the interwar period. Thus, together with the evidence on the extent of capital flows, this subsection again offers support for the view that the Depression marked a low point in the modern history of international capital mobility.

\section{World War I and the Interwar Period}

World War I demonstrated the capacity of governments to radically alter exchange rates and price levels, often with the assistance of explicit controls beyond and above normal central bank operations. These newly found powers were not quickly forgotten. In the early 1920 s, they were used to ease the deflationary adjustments of economies seeking to re-peg to gold, and were abused in the monetary mayhem surrounding the hyperinflations in several European states. As the fleeting interwar gold-exchange standard took form after 1925 the older laissez-faire approach to the exchanges was briefly reestablished as many countries eliminated or relaxed exchange controls, but the international financial crisis of 1931 dealt a final blow to the old orthodoxy. Sterling's departure from its gold peg in September 1931 heralded the demise of the gold-based system as well as the return of exchange controls, "in many ways to an even greater extent than during and after the war" (Einzig 1934, pp. 1-2). Out of the resulting economic and political 
turmoil would emerge the new consensus on international macroeconomic coexistence embodied in the Bretton Woods agreement of 1944.

The effectiveness of exchange controls varied greatly. Naïve policies contained loopholes through which regulations on capital flows might be evaded. Certain controls proved hard or even impossible to implement, but others, when sufficiently refined by the increasingly cunning authorities, served their purpose. A measure of the impact of such policies was the common appearance of the "black bourse" in some of the most tightly controlled economies. Free-market rates often diverged widely from official rates. This added further uncertainty to foreign exchange markets already subject to frequent, often violent, fundamental movements after floating rates appeared in the wake of gold-standard suspensions during and after World War I. With the world's nominal anchor removed, massive exchange risks reentered the calculation of every foreign investor. Controls, if they threatened to compromise the secure and full repatriation of profits or principal, heightened risk further and could prompt capital flight or the collapse of lending. Speculative activity in new instruments offered by the forward market, and the emerging threat to central banks and treasuries posed by increasing volumes of highly liquid, "hot" money, prompted even greater caution in the bureaucratic supervision of foreign-exchange transactions. Exchange controls thus compounded a deteriorating framework for international capital flows.

\subsection{World War I and the Return to Gold}

Direct controls over private exchange transactions were rarely employed under the gold standard before 1914. Central banks occasionally used "normal" measures to support exchange rates, broadly defined to include moral suasion over banks, direct interventions to alter gold export and import points, and other formally noncoercive devices. But if a central bank could no longer defend the exchange rate through such measures, as often occurred in Latin America, it was generally set free to float with no control employed. Within Europe, the credibility of exchange parities was bolstered by Britain's hegemony within the world financial system and its espousal of free trade, as well as by central-bank cooperation and the overriding and largely unquestioned commitment of central banks to the goal of gold convertibility at an unchanging par (Kindleberger 1986; Eichengreen 1992b). Credibility ensured 
that capital movements were usually stabilizing. The high degree of international capital mobility was promoted by the gold-standard regime; and by reducing actual gold movements, capital mobility in its turn helped the system to function smoothly.

The Great War destroyed this equilibrium, and the classical gold standard too. Initially, countries kept up the appearance of the gold standard, maintaining official gold coinage, pegging official exchange rates, and, on paper, permitting the movement of gold; but obstacles and regulations, as well as heightened susceptibility to patriotic appeals, prevented normal functioning according to the rules of the game (Eichengreen 1992b, p. 67). The belligerent countries were the first to enforce controls. Wartime needs drove their trade balances into deficit, and monetization of fiscal deficits drove inflation, though to widely differing degrees in the several countries. Although exchange control became an "obvious necessity" in these circumstances, countries did not produce a full-blown, cut-and-dried system of controls at the outbreak of war. A gradual implementation of ever-stricter controls ensued, although trading with the enemy was quickly terminated. In 1914 and carly 1915, belief that the war would be short and swift kept the exchanges fairly stable. It was not until later in 1915 that general foreign exchange transactions came under restriction as the exchanges became more volatile (Brown 1940, pp. 59-63; Einzig 1934, pp. 22-23; League of Nations 1938, p. 9).

Allied experiences varied considerably. The British began in 1915 by pegging the dollar rate of sterling, with the British Treasury acting via J. P. Morgan in New York to support sterling at $\$ 4.7640$ using gold and dollar reserves. In the early war years the country often came near to exhausting its reserves, as recounted by Keynes (1978, pp. 10-12). After 1917, it was the U.S. Treasury that supplied the required funds, and the peg continued. France employed similar methods to defend a franc-sterling peg, albeit, with both "passive" and "active" intervention by the Bank of France. In the later stages of the war, exchange controls grew much stricter than in Britain. Whereas appeals to patriotism and other types of moral suasion had sufficed to discourage outbound capital transfers for a while, in the end tougher measures were needed. France's more severe inflation problems undermined the credibility of the peg and capital outflows were harder to tame. Italy likewise pursued a policy of pegging against sterling. Apart from Britain, France, and Italy, no allied power sought to peg, but all resorted to exchange 
controls toward the end of the war. Even the U.S. applied direct controls after entering the war in 1917, despite its strong trade balance, as a result of the dollar's appreciation against several neutral currencies (Einzig 1934, pp. 28-9; Eichengreen 1992b, p. 73).

In Germany, the mark was never pegged to another currency during the war, and the Reichsbank spent a mere 450 million marks on intervention to defend the mark in times when depreciation threatened to become a burden-a tiny fraction of the inter-Allied resources devoted to currency support. However, Germany's trade was effectively blocked by the Allies, so her adverse net export balance was rather small. Exchange restrictions did not come into force until 1916, and were only mild until they were dramatically reinforced in 1917 (Einzig 1934, pp. 29-30). Still Germany employed strong forms of compulsion to mobilize residents' foreign securities (Eichengreen 1992b, p. 83).

The Armistice gave hope that wartime exchange controls would soon be removed and the pre-war state of affairs would soon prevail. The removal of controls was one of the few things the Brussels Conference of the League of Nations (1920) could agree on (Eichengreen 1992b, pp. 154-55). In the United States exchange control was dismantled, and in Britain controls had largely ended by the time sterling rejoined the gold standard in 1925 . The dollar peg ended in March 1919, and sterling was cut loose to take care of itself. The authorities refrained from direct measures; however, occasional weak embargoes on British foreign loans were enforced starting in 1924 to bolster the currency as it inched back toward gold parity, and later in the 1920s. ${ }^{12}$ By floating in 1919, Britain was able to open its capital market relatively quickly after the war's end. Elsewhere, however stability proved elusive, and exchange controls had to be maintained or reinforced after the war as many countries descended into economic chaos (Einzig 1934, chaps. $4-5)$.

When inter-Allied support ended, a rapid flight from the franc ensued with rampant bear speculation, and the Bank of France remained neutral and impassive, preferring to husband its gold stock rather than intervene in a probable losing cause. Harsh exchange controls were promulgated, but it was not until after the franc stabilized in 1926, and vast sums were repatriated, that all could see how ineffective the controls had been. Moreover, other policies impinged on capital flows, notably the fierce controversy over the 
capital levy. With a broader franchise, political groups representing labor now tried to force capital to shoulder a larger part of the fiscal burden. Deadlock persisted as governments came and fell. In 1925, the capital levy was adopted by the government, a 10 percent tax on all wealth over ten years, and although it was later rejected by Parliament, it remained a possible option through 1925 and 1926. The idea was only killed for good by the Poincare government's fiscal stabilization package in late 1926, but in the interim, the lingering possibility of a wealth tax sent capital fleeing abroad (Einzig 1934, chaps. 4-5; Eichengreen 1992b, pp. 172-79).

As inflation seized Germany's economy between 1919 and 1923, many measures were taken to halt the slump in the mark by intervention and exchange restrictions. But the German gold stock was quickly frittered away in a futile effort, leaving ever tighter exchange controls as the only defense. Exporters and importers had all exchange requests subject to government approval, and indirect controls centered on import restrictions. Even so, capital flight from Germany went on unabated and the black bourse in Cologne became a major point of leakage. Exchange controls in the successor states of the Austro-Hungarian empire took even more esoteric forms. ${ }^{13}$ In Italy, the postwar Fascist regime enjoyed greater success in controlling the exchanges, however, largely as a result of its extraordinary powers of enforcement.

In most countries, restrictions eventually were relaxed following stabilization. Still, there were delays; for example, although the mark stabilized in 1923, the last restriction was not removed until 1926. And very often, stabilization had only been achieved by dint of exchange controls in the interim. Nonetheless, by 1927, most of the world's market economies had returned to "normalcy" in the form of pegged exchange rates and some form of gold standard.

\subsection{Interwar Exchange Control}

In sharp contrast with the laissez-faire approach normal during the classical gold standard era prior to 1914, the interwar period saw a marked increase in the adoption of policies to control not only international capital flows but foreign exchange transactions in general (Einzig 1934; Gordon 1941). Controls over foreign-currency transactions took several forms. In assessing how controls affect capital mobility, we are primarily concerned with measures 
that would have been viewed as "abnormal" under the gold standard---steps taken to defend or change the course of the exchange, and covering direct measures such as loan embargoes and foreign exchange rationing or "indirect" measures to influence the foreign trade or foreign loan markets. Such measures were attempted fitfully in the $1910 \mathrm{~s}$ and $1920 \mathrm{~s}$, but their reappearance in "extreme forms" dated from the crisis of 1931 (Bratter 1939, p. 274). ${ }^{14}$

Such interventions served a variety of purposes of concern to the policy makers: to counteract the transfer of liquid balances, the flight of national capital, the possibility of speculation, fluctuations in the trade balance, or the exchange controls of other countries. Controls could be called upon to offset mere day-to-day fluctuations or problems, to stem persistent speculation or capital flight, to smooth predictable seasonal and other normal tendencies, or to attempt to reverse fundamental trends. In many cases such attempts to distort capital-account transactions were also complemented by commercial policies (tariffs and quotas) aimed at inhibiting the volume of current-account transactions. In fact, given the balance of payments identity, policy makers viewed certain exchange control and tariff policies as pure substitutes. ${ }^{15}$ From a macroeconomic viewpoint, controls enabled a government to maintain (at least nominally) a pegged exchange rate, while simultaneously using interest-rate policies and other policies based on divergences between internal and external prices to attain domestic economic objectives.

Exchange controls became "among the best-hated" forms of government interference in free markets in the eyes of observers and market participants (Einzig 1934, p. 106). Controls were criticized for causing exchanges to diverge from their fundamental level (though identifying fundamental levels proved elusive in the interwar chaos), and for their damaging effect on international trade and finance (though the effect of exchange controls here could not be easily differentiated from the corrosive effects of tariffs, quotas, and other commercial policy choices). Even if not implicated on these charges, exchange controls were subject to even more stinging criticism, facing ridicule for being "utterly inefficient and impossible to enforce" (Einzig 1934, p. 107). The nettlesome interferences with the exchange were thus in vain, critics charged, on account of weak policing and enforcement, and the numerous loopholes which savvy exchange dealers could easily exploit to circumvent the intent of the restriction. If the speculators proved strong enough for the task, the authorities faced certain defeat, and the incentive 
to exploit loopholes only loomed larger as the exchanges moved further from fundamentals, inviting arbitrage. Such was undoubtedly a major weakness of the early and rudimentary controls seen in the 1920s, as in the French and Belgian cases. Embargoes on loan issues might fail if investors were willing to purchase issues in a third country, or if short-term trade credits could be disguised and employed to finance longer term capital flows. Partial controls could be futile, as transactions might be easily disguised in false categories, necessitating full-blown supervision of every transaction (Nurkse 1944, p. $165)$.

Evasion could never be totally eliminated, but authorities learned the lessons of failed controls and became more ruthless in imposing and enforcing trading restrictions as the 1930 s wore on. All countries had access to a variety of measures, beginning with unofficial discouragement of capital export through moral suasion, official prohibition with the cooperation of the banks, or the direct prohibition without the help of the banks. More desperate measures included even more restrictive allocations of exchange for loans and import, the compulsory surrender of export proceeds, and, finally, the complete suspension on free dealings, i.e., a crackdown on the black bourse. ${ }^{16}$ By the 1930 s the criticism the controls were ineffectiveness could be said to have lost much of its force (Einzig 1934, p. 112). Capital controls were now binding on the global capital market to an unprecedented extent. Although devised primarily as a response to short-run problems with capital flight, even the prospect of modest barriers to outward flows undermined the efficient allocation of global capital. As Ellis (1941, p. 22) succinctly summarized, capital controls "may interfere with the tendency of capital to bring its marginal employments to equality and thus maximize yields.... in preventing capital repayments, exchange control effectively discourages the investment of new foreign capital. Since the 'natural' direction of capital-flow was toward the debtor (now exchange-control) countries, this is probably the more serious consequence." In addition, distributional conflicts over the tax burden raged on between labor and capital, and the possibility of a capital levy in many countries "hung over investors like a fiscal sword of Damocles, discouraging saving, provoking capital flight, and heightening the fiscal crisis" (Eichengreen 1992b, p. 107). All of these factors contributed to the dramatic fall in international capital mobility documented in section 1 above. 


\subsection{Controls as a Reaction to the Great Depression, 1931-1939}

The global Great Depression and the financial instability accompanying it were directly responsible for the sharp turn toward exchange control in much of the world. Stability on the exchanges came to an abrupt end in 1931, though trouble had been brewing longer in many countries, especially at the periphery (Einzig 1934, chap. 6; League of Nations 1938, pp. 10-11; Ellis 1941, p. 7; Yeager 1976, chap. 17). Currency crises in 1931 led to flights from the Austrian schilling, the Hungarian pengö, and the German mark following the Creditanstalt collapse. It appeared that exchange control might be the only policy alternative since when "flight psychology" prevailed "no increase in the discount rate may be sufficient to deter it. Indeed an increase in the discount rate, by shaking confidence further, is apt to produce the opposite effect"; yet, confoundingly "the introduction of control itself...tended to upset confidence further, increasing the urge to export capital" making the exercise "self-aggravating to some extent" (Nurkse 1944, pp. 162-63). Policymakers groped for a solution.

In June a flight from sterling began, leading to gold standard suspension in September. Facing high unemployment, the British government had no stomach for an aggressive defense of the pound through budgetary retrenchment, which would have required scaling back the dole. Nor did the Bank of England carry out an aggressive interest-rate defense. Instead bank rate was raised shortly before the announcement of the gold standard's suspension "as a measure of reassurance against inflation" (Saycrs 1976, p. 412). Soon the dollar and Dutch guilder were exposed to runs, and flight from the yen drove Japan off gold before year's end. Not all currencies fell from gold immediately, but the fear grew. In such circumstances, exchange controls inevitably returned to prominence: governments fought off depreciation and convertibility crises with intervention, exchange restrictions, and other forms of exchange control (Nurkse 1944, chap. 7).

Simple intervention usually proved ineffective in the face of continued gold drain, as with Germany, Austria, and Hungary in the summer of 1931. Reserves were spent in a futile effort. Coffeehouse transactions on the black market soon undermined rationing through the banks. German restrictions were severe, foretelling the blocked balances and other obstructions to come. In July 1931 a partial transfer moratorium was announced, suspending prin- 
cipal payments, and later extended in a full Standstill Agreement with Germany's creditors. Only thus was a collapse of the mark prevented. Both Austria and Germany's banking systems stood on the verge of collapse, and choosing to sacrifice gold convertibility for bank stability, the governments adopted exchange control.

In the fall of 1931 Britain promulgated several mild exchange restrictions following suspension and lasting for six months, primarily to prevent capital flight. In general during the 1930s, Britain employed relatively limited controls, ranging from persuasion, to an embargo on large foreign bond issues, to official restrictions applied by banks which remained loyal to policy goals. But these measures were far from comprehensive. ${ }^{17}$ The United States, under the Hoover administration, continued to maintain dollar convertibility into gold at $\$ 20.67$ per ounce. As an accompaniment to President Roosevelt's suspension of gold convertibility in 1933, however, the United States began to deploy informal pressures similar to those used in Britain, though occasionally enforcing official supervision of banks when an assumption of loyalty could not be taken for granted.

In Japan, back on gold only since 1930 and suffering the fiscal strains of the Manchurian campaign, a gold embargo was applied to stem severe losses in 1932; depreciation heralded the end of convertibility and the application of more restrictions on foreign exchange to prevent capital flight. France also generally avoided direct measures, relying on tariffs, quotas, and other commercial policies to kecp the trade balance favorable and gold stocks plentiful - but the gold bloc could not hold on forever (Yeager 1976, chap. 18). Italy's government made very effective use of unofficial restrictions by dint of the powerful command of the banking system at central government level, and capital flight in 1935 forced Belgium into very stringent controls (Einzig 1934, chap. 6; Eichengreen 1992b, chap. 9). ${ }^{18}$

The tendency toward the forcible confinement of foreign exchange within borders was perhaps most famously institutionalized in the widespread adoption of the system of "blocked balances" in continental and Latin American countries, and notably in Germany under the Gold Discount Bank (Einzig 1934, chap. 12; Ellis 1941, pp. 13-17). Simply put, "blocked currencies" enshrined the idea that debtors could make debt payments not with foreign exchange but with domestic currency placed in special, earmarked accounts, funds which the creditor might only then use in limited ways, for renewed 
direct investment in the debtor country, or to buy more of the debtors exports. Thus, the "blocked account" became a new payoff option unilaterally imposed by debtors, and effectively defaulting on the terms of their original loan contract. ${ }^{19}$ Moreover, the payment into a blocked account was often illusory as a financial transaction, entailing no shift in the structure of international indebtedness, affording no liquidity to the debtor, and usually enforcing no loss of liquidity on debtor banks which often maintained currency issue backed by "blocked accounts." 20 Owing to this vehicle for credit creation, the "blocked accounts" were easily manipulated "for disguising the insolvency of the debtors, and especially of one particular debtor - the Govermment of the debtor country" (Einzig 1934, pp. 126--27). Thus an insolvent govermment might payoff debts into its "blocked account" then re-lend to itself out of the same funds. Inevitably, claims on such "blocked accounts" soon began trading on the secondary market at a heavy discount. An international market soon developed in the 1930s for four types of German marks, six types of Hungarian pengöes, and many other "blocked currencies." Market rates diverged dramatically from the official par rates of the exchange-controlled domestic currency. ${ }^{21}$

Germany, Austria, and Hungary all developed complex systems of "blocked currencies" and bilateral clearings (Ellis 1941; League of Nations 1938, p. 16; Yeager 1976, pp. 368 71). Many other countries in Central and Southern Europe followed suit, causing the return of virtual barter conditions in many goods markets, and stifling foreign investment. However, the German case remains the example par excellence of this type of exchange control-and by the late 1930s it had persisted beyond the point where it was economically defensible, seeming more a tool of national and international political power via favorable allocations of trading activity to domestic agents and foreign trading partners. Thus, after the immediate 1931 crisis, the reasons for keeping exchange control mutated, and the control "introduced in the first instance mainly to prevent capital exports[,] soon shifted its emphasis to the control of commodity imports..." (Nurkse 1944, p. 166). Political as well as economic concerns surfaced, with the free market or black bourse as the only recourse for all but a few restricted transactions. "De facto and sub rosa devaluation transformed the official rate of exchange to a mere face-saving fiction" (Ellis 1941, p. 293).

In contrast to Germany, Austria, long before anschluß, was already relax- 
ing controls (Ellis 1941, chap. 2). Comparable measures to relax exchange controls and bilateral constraints were to be seen in Romania, Yugoslavia, Hungary, Czechoslovakia, Bulgaria, and elsewhere in the exchange-control bloc (League of Nations 1938, pp. 40-5). Bilateral exchange clearing was beginning to be seen as a welfare-reducing, trade-diverting choice justified by "ulterior ends"; one such end was protection, which "appeared as a byproduct of attempting to defend the currency, but it proved to be so welcome a by-product as certainly to become an end itself" (Ellis 1941, p. 297). By obstructing trade along lines of comparative advantage, clearings frequently depressed domestic exports, only exacerbating the shortage of foreign exchange that exchange controls were supposed to alleviate. More and more countries turned away from trading under such constraints with countries in the clearing bloc (League of Nations 1938, pp. 24-37; Nurkse 1944, pp. $177-83){ }^{22}$

In Latin America, countries both depreciated their currencies and joined the movement toward exchange control as depression decpened and after sterling left gold (Bratter 1939; Nurkse 1944, p. 162). Most also defaulted on their foreign debts, an event which had a profound negative impact on subsequent capital inflows to the region, as many defaults were not settled until the 1940s and even the 1950s (Díaz Alejandro 1983, p. 27). Controls were initially a response to balance-of-payments crises resulting from a collapse of primary product prices and quanta in export markets, the stickiness of import demands, and large fixed nominal debt obligations. However, controls were generally less rigid than in Europe, with a liberal attitude taken to the foreign exchange transactions outside normal channels - thus, some capitalaccount transactions were permitted and black markets were tolerated, whilst in Europe such flows were strictly controlled; and Latin American countries were generally less inclined to adopt bilateral clearing arrangements save under duress (League of Nations 1938, p. 17; Nurkse 1944, p. 170). The key instrument was the rationing of exchange for different uses according to government priorities, implying multiple exchange rates (League of Nations 1938, p. 15). High priorities were usually debt service (unless in default) and essential imports. ${ }^{23}$ The more "reactive" countries soon adopted controls: Argentina, Bolivia, Brazil, Chile, and Colombia (in 1931); followed by Costa Rica, Nicaragua, Paraguay, and Uruguay (1932); Ecuador (1933); Honduras (1934); and Venezuela (1936). ${ }^{24,25}$ 
Argentina, Brazil, Chile and Colombia were locked in clearing agreements with Germany, and these plus Costa Rica and Uruguay controlled trade along bilateral lines via exchange controls or clearing agreements. Such arrangements had marked consequences for regional trade, and a good deal of Latin American trade was canalized bilaterally not by choice, but by the actions of European trading partners, and to the detriment of rival markets. In many countries, trading with Nazi Germany under ASKI ("compensation") marks was seen to have dramatically altered the composition of trade. ${ }^{26}$ Although the Pan American Union called for moves to abolish controls in 1936, the 1937 recession again exposed the underlying weakness of the periphery's balanceof-payments position, and no concrete action was taken to lift controls before the war (Bratter 1939, p. 286).

Australia was also typical of peripheral primary-producers caught in a balance-of-payments crisis and facing unsustainable capital outflows as early as 1929. The terms of trade had dived from a peak in 1924, reflecting oversupply in the wool market. Mild controls appeared first in the form of foreignexchange rationing, and soon the currency slipped outside the gold points. It was 8 percent off par by April 1930. A steady devaluation ensued, and a black market appeared, compromising the policy of rationing via the banks. Eventually the system broke down and the currency was devalued to 30 percent below par at the start of 1931. Canada, followed similar steps to limit gold export and convertibility, inevitably leading to devaluation of her currency (Eichengreen 1992b, pp. 232-36 and p. 240).

\subsection{Policy Outcomes}

Once the initial crisis of 1931 passed, policy makers faced a choice: on the one hand they could treat exchange controls as a temporary expedient for the crisis and thereafter work towards free exchanges, sacrificing policy autonomy; or else they could retain and enhance the security of their controls, and so expand the range of policy options. Thus, by the late 1930s, countries could be classified as "free-currency countries" (whether on or off the Gold Standard) or "exchange control" countries (League of Nations 1938; Eichen-

green 1992b, p. 339). (Of course, even countries in the former group) could employ informal measures of capital-account control, such as moral suasion, in the interest of exchange-rate or balance-of-payments targets.) Table 3.1 il- 
lustrates some of the contrasts between the exchange-rate experiences of the two groups. The "free" group included much of Scandinavia and Western Europe. Among these, Belgium, the Netherlands, Switzerland, and France (along with the U.S. until 1933) were in the "gold bloc" and avoided devaluation only through strong "indirect" measures (e.g., tariffs and quotas) in the early 1930s. By contrast, "controlled" economies included Germany, Austria, Hungary, and neighboring countries to the east, plus Turkey, Italy, and two Baltic states - a largely Central and Southeastern European grouping. In the latter group, generally severe exchange controls allowed governments the freedom to maintain parities (or tolerate only relatively mild devaluations) without fear of speculative attacks, as capital flight was severely contained. ${ }^{27}$

Recent academic writing has emphasized the role of the international gold standard in propagating the Great Depression, showing systematically how countries that maintained gold parities and continued approximately to follow other gold-standard "rules of the game" through the mid-1930s suffered much sharper output declines and deflation ${ }^{28}$ Countries willing to devalue could lower the relative price of national output and expand their money supplies, boosting effective demand and employment while retaining a relatively open capital market. Exchange control countries addressed the macro policy trilemma by eliminating capital movements. While officially maintaining 1931 gold parities, these countries effectively devalued their currencies through a maze of restrictions on foreign exchange acquisition. Elimination of dependence on international capital markets in some cases increased the scope for domestic fiscal expansion, as in Germany. But countries in the gold bloc, despite resort to conventional trade policies, felt the full force of the policy trilemma, maintaining initial gold parities and free foreign exchange markets only at the cost of a deep and protracted domestic slump.

Econometric evidence points to independent roles for controls and exchange depreciation in mitigating the effects of the Depression. The equation below is a 26-country cross-section regression of the 1929 to 1935 cumulative rate of growth of industrial production, $\triangle I P$, on a constant (estimate not reported) and two dummy variables. FIXED takes the value 1 for countries that held their official exchange rates fixed at 1929 levels longer than the United States (which severed the dollar's link to gold in April 1933), and takes the value 0 for others. CONTROLS equals 1 for countries classified by the League of Nations in the mid-1930s as exchange-control countries, 
Table 3.1

Currency Depreciation in the 1930s

Percentage Depreciation Relative to Official Gold Parity

\begin{tabular}{|c|c|c|c|}
\hline \multicolumn{2}{|c|}{ Exchange-Control Countries } & \multirow{2}{*}{$\begin{array}{r}1932 \\
0.0\end{array}$} & \multirow{2}{*}{$\begin{array}{r}1935 \\
0.0\end{array}$} \\
\hline Bulgaria & (a) & & \\
\hline Germany & (a) & 0.0 & 0.0 \\
\hline Hungary & (b) & 0.0 & 0.0 \\
\hline Romania & (a) & 0.0 & 0.0 \\
\hline Latvia & (a) & 0.0 & 1.7 \\
\hline Turkey & (a) & 1.7 & 1.9 \\
\hline Italy & (a) & 1.5 & 6.3 \\
\hline Czechoslovakia & (a) & 0.0 & 16.2 \\
\hline Austria & (a) & 22.0 & 22.0 \\
\hline Yugoslavia & (b) & 6.8 & 23.0 \\
\hline Estonia & (b) & 0.0 & 39.9 \\
\hline Denmark & (b) & 29.7 & 51.5 \\
\hline Uruguay & (b) & 54.5 & 53.9 \\
\hline Argentina & (b) & 39.4 & 54.3 \\
\hline \multicolumn{4}{|c|}{ Free-Currency Countries (Gold Bloc) } \\
\hline France & (a) & 0.0 & 0.0 \\
\hline Netherlands & (a) & 0.0 & 0.0 \\
\hline Switzerland & (a) & 0.0 & 0.0 \\
\hline Belgium & (a) & 0.0 & 3.2 \\
\hline Poland & (a) & 0.0 & 0.0 \\
\hline \multicolumn{4}{|c|}{ Free-Currency Countries (Devaluers) } \\
\hline Ireland & (b) & 28.0 & 40.2 \\
\hline South Africa & (b) & 2.1 & 40.8 \\
\hline United States & (a) & 0.0 & 40.8 \\
\hline Canada & (b) & 11.9 & 40.9 \\
\hline United Kingdom & (a) & 25.2 & 41.9 \\
\hline Sweden & (a) & 25.9 & 45.6 \\
\hline Norway & (a) & 26.9 & 47.0 \\
\hline Finland & (a) & 36.4 & 50.4 \\
\hline New Zealand & (b) & 34.2 & 52.3 \\
\hline Australia & (b) & 42.5 & 52.6 \\
\hline
\end{tabular}

Notes: (a) denotes annual average; (b) monthly average for March of 1932 or 1935.

Source: League of Nations (1938, pp. 50-51). 
and is 0 for "free-exchange" countries. (The exchange-control group comprises a wide variety of control strategies, some much more stringent than others, and omits countries that applied controls only fleetingly.) The result of estimation (with standard errors in parentheses) is:

$$
\begin{aligned}
& \Delta I P=0.028-0.261 \text { FIXED }+0.213 \text { CONTROLS, } \\
& (0.060) \quad(0.080) \quad(0.079) \\
& R^{2}=0.41
\end{aligned}
$$

As is now well known, countries that retained fixed exchange rates suffered harsher real contractions. According to the preceding equation, they experienced (on average) over the years 1929 to 1935 a $26 \%$ output decline avoided by countries that devalued. However, controls (which usually implied de facto devaluation) had a significant mitigating effect on the extent of output decline due to fixed exchange rates. ${ }^{29,30}$

The output effects of controls are mirrored by the behavior of the price level, as shown in the following regression in which the dependent variable is the cumulative 1929 to 1935 rate of wholesale price index inflation:

$$
\begin{aligned}
& \triangle W P I=-0.157-0.227 \text { FIXED }+0.082 \text { CONTROLS } \\
& (0.026) \quad(0.035) \quad(0.034) \\
& R^{2}=0.66
\end{aligned}
$$

Here we see again the familiar deflationary effect of fixed exchange rates, but also a significant counter-effect of controls on the price level. Though statistically significant that effect is small, because the "devaluation" implied by controls did not generally lead to significant monetary expansion relative to the world average.

Fundamentally, these diverse experiences underscored the unattainable nature of the economic "trinity": of three desirable policy goals, exchangerate stability, full employment, and free capital mobility, only two out of three are mutually compatible. The free-currency group discarded exchange stability and gained the freedom to pursue expansionary fiscal and monetary policies. The exchange-control countries sought the same freedom by inhibiting capital mobility, and, further, manipulated the levers of thoroughgoing exchange control and discriminatory trading in pursuit of domestic goals. Notably, neither group considered a full return to gold-standard orthodoxy, 
requiring the neglect of the full-employment goal and commitment to the other two goals, exchange parity and free exchanges--a testament to the sea change in the political economy of macroeconomic management, the power of new interest groups and enfranchised voters, and the resulting unwillingness of governments to tolerate deflation and labor unrest in a distributional fight under conditions of downward wage inflexibility (Eichengreen 1992b).

Much of the motivation for maintaining pegged exchange rates, both in gold-bloc and exchange-control countries, was the fear of hyperinflation and the attendant social conflict, as witnessed all too recently in central and eastern Europe. That fear was present, though not dominant, even in countries that chose open devaluation (see Eichengreen 1992b, p. 292; Nurkse 1944 , p. 166; Sayers 1976, p. 412). Ironically, exchange control, itself so inimical to the liberal principles of orthodox finance, nonetheless facilitated the persistence of orthodox monetary policies in those countries least willing, given recent inflationary experience, to sacrifice the nominal anchor of their official gold parity. Even in peripheral Latin America, "memories of wild inflation under inconvertible paper during the late nineteenth century, memories still fresh during 1929 1931, hampered and slowed down the adoption of more self-assured and expansionist policies" (Díaz Alejandro 1983, p. 18).

The exchange-control countries, burdened by foreign debts and precarious reserve levels when the 1931 crisis hit, could maintain their exchange parities in no other way but through controls. Once in place, however, controls were in most cases difficult to contain and were found to have other uses (albeit at foreigners' expense). The gold-bloc countries, in contrast, had the financial resources to cling to gold parities without radical controls, but as a result were defenseless against the deflationary forces of the Depression. As much as anything, the experience of these countries discredited the last adherents of gold-standard orthodoxy and opened the way for the new and interventionist Keynesian approach to international monetary relations that would prevail after the second World War. 


\section{World War II, its Aftermath, and the Resurgence of Capital Mobility}

Private international capital mobility reached a nadir during and after World War II, with much of the world left in the grip of bilateral payments arrangements. The postwar international economic order agreed at Bretton Woods in 1944, and inaugurated with the declaration of currency par values in 1946, mandated convertibility for current-account, but not necessarily for capital-account transactions. Even current-account convertibility proved hard to attain, however, in the circumstances following the war. Only at the end of 1958 was external (i.e., nonresident) convertibility on current account restored for the main European currencies. ${ }^{31}$ The following decade was characterized by increasing capital mobility, but also by speculative tensions that prompted industrial countries to intensify capital controls in an attempt to shore up the system of fixed exchange rates. These measures proved insufficient, and the modern era of floating dollar exchange rates finally dawned in 1973. Since then, the international flow of capital has expanded dramatically.

\subsection{Wartime Intensification of Exchange Control}

The onset of renewed war in 1939 led to an intensification of exchange control. In a memorandum written for British Treasury officials in September 1939, Keynes recalled of the emergency measures taken during World War I, "[c]omplete control was so much against the spirit of the age, that I doubt, it, ever occurred to any of us that it was possible" (Keynes 1978, p. 10). Countries drew heavily on their interwar experiences with controls to mobilize their foreign-exchange resources for all-out conflict. By March 1940, dealings in nearly all the world's major currencies, the two important exceptions being the United States dollar and the Swiss franc, were subject to some form of exchange control (Mikesell 1954, p. 15). An additional advantage of restricting capital outflows in wartime was that governments might thereby borrow at artificially low rates of interest.

Britain introduced controls in August and September of 1939, initially regulating residents' purchases of foreign currencies but not blocking sterling balances held by nonenemy aliens or preventing all sterling transactions between residents and nonresidents. An offshore market in "free" sterling 
consequently developed. As Keynes (1978, pp. 158-71) forcefully pointed out, nonresidents could buy British exports with free sterling, thus depriving the country of badly needed hard currency - basically, U.S. dollars or Swiss francs. This loophole and others were closed early in June 1940 (Mikesell 1954, p. 16), the same month Keynes took up a formal advisory position at the Treasury. ${ }^{32}$ The interwar sterling bloc, previously a loose association of countries pegging to the pound, narrowed its membership and transformed itself into the Sterling Area, within which similar exchange controls were enforced but internal currency transaction, including capital movements, were free. ${ }^{33}$

\subsection{Capital Mobility in the Bretton Woods Blueprint}

Well before the end of the war, officials in allied treasuries were turning their minds toward designing a postwar international economic order. In 1941 and 1942 respectively, John Maynard Keynes in Britain and Harry Dexter White in the United States circulated different draft plans for postwar institutions designed to aid in the maintenance of exchange stability, macroeconomic stability, and orderly, generally nondiscriminatory trading relations among nations. White's plan would, in 1944, become the basis for the Bretton Woods agreement that led to establishment of the International Monetary Fund (IMF), World Bank, and the General Agreement on Tariffs and Trade (GATT). Both plans are instructive, however, for the light they throw on official and academic attitudes toward the role of capital movements. ${ }^{34}$ In essence, the plans reflected a broad policy consensus, growing out of the experience of the Depression, that the global economy would not necessarily be smoothly self-regulating were wartime controls to be dismantled, so that, exchange rates and international capital movements would both have to be closely controlled. ${ }^{35}$

Keynes's plan stepped back from the extreme economic nationalism he had flirted with in his famous 1933 article on "National Self-Sufficiency" (Keynes 1982, pp. 233-46). ${ }^{36}$ But the plan's basic premise was that heavy government management of macroeconomic policies and exchange rates should be deployed in the defense of internal macroeconomic stability, and that such a resolution of the policy trilemma presupposed extensive restrictions over, not only capital movements, but foreign exchange transactions in general. 
Keynes's plan proposed an International Clearing Union (ICU) which would facilitate multilateral trade among members and extend credit (within limits) to cover current-account deficits. To these ends, countries with external surpluses would accumulate claims on the ICU, and countries with deficits, liabilities. Such credits of "bancor" as the new international currency was called, fixed in gold value and in terms of national currencies, would be used by countries to settle international accounts, much as gold had been in an earlier cra. The instability associated with fluctuating interwar exchange rates remained a powerful influence over attitudes toward postwar monetary relations. In Keynes's view, floating rates were to be rejected both for their disruptive effects and as a reversion to discredited laissez-faire economics.

Exchange values under the ICU were not to be "unalterably" fixed, however; far from it. Instead Keynes's conception, as expressed several years later in defending the proposed International Monetary Fund in the House of Lords, was that

We are determined that, in future, the external value of sterling shall conform to its internal value as set by our own domestic policies.... [I]nstead of maintaining the principle that the internal value of a national currency should conform to a prescribed de jure external value, [the Bretton Woods plan] provides that its external value should be altered if necessary to conform to whatever de facto internal value results from domestic policies, which themselves shall be immune from criticism by the Fund. (Keynes 1980b, pp. 16-18)

In other words, exchange realignments rather than domestic deflation, as under the gold standard, would be the preferred tool for rectifying payments deficits and unemployment in Keynes's system. Domestic policies would be geared toward high employment, with short-term international imbalances being met by overdrafts on the ICU. Keynes's view on exchange rate adjustment represented a sea-change in the attitudes that had prevailed in the Gold Standard era. As Haberler (1976) puts it in an insightful discussion of the Great Depression's causes and legacy:

The sanctity of fixed exchange rates was a casualty of the Great Depression. It is true that there had been many exchange-rate 
changes in the nineteenth century and earlier. But the devaluation of the leading currencies of the world . . . made the operation "salonfähig," that is, fit for gentlemen.

Keynes appreciated clearly that by resolving the policy trilemma in favor of internal employment goals and exchange-rate management, he was ruling out open capital markets. Indeed, Keynes's plan embraced exchange control wholeheartedly and explicitly called for curbs on capital movements, with some provision for international long-term capital movements added in as an afterthought. ${ }^{37}$ The attitude toward private capital movement was set out explicitly in all drafts of Keynes's plan, for example, the fourth: ${ }^{38}$

It is widely held that control of capital movements, both inward and outward, should be a permanent feature of the post-war system- at least so far as we are concerned. If control is to be effective, it probably involves the machinery of exchange control for all transactions, even though a general open licence is given to all remittances in respect of current trade. But such control will be more difficult to work, especially in the absence of postal censorship, by unilateral action than if movements of capital can be controlled at both ends. It would therefore be of great advantage if the United States and all other members of the Currency Union would adopt machinery similar to that which we have now gone a long way towards perfecting in this country; though this cannot. be regarded as essential to the proposed Union. (Horsefield 1969, p. 13)

White's alternative plan placed less emphasis on periodic exchange-rate adjustment than did Keynes's, and viewed capital movements in a somewhat more favorable light. Dam (1982, p. 83) quotes a passage from the April 1942 version of the White plan (Horsefield 1969, p. 47) to support the assertion that White took a creditor's view of the postwar order, favoring reduced capital controls in contrast with "Keynes's enthusiasm for capital controls." In fact, White was referring to generalized exchange controls on the model of interwar Germany in the quoted passage, not specifically to capital controls, and later in the plan (Horsefield 1969, pp. 49-50) advocated a prohibition of Fund resources for funding "illegitimate" capital flows. Such a provision 
would have been necessary in any event to assuage Congressional fears that the U.S. would end up funding unlimited foreign imbalances. White's plan also called for international cooperation to limit capital flows inspired by "speculation" or tax evasion:

It would be an important step in the direction of world stability if a member government could obtain the full cooperation of other member governments in the control of capital flows....The assumption that capital serves a country best by flowing to countries which offer most attractive terms is valid only under circumstances that are not always present....A good case could be made for the thesis that a government should have the power to control the influx and efflux of capital, just as it has the authority to control the inflow and outflow of goods and of gold. (Horsefield 1969 , pp. 66-7)

In reality, Keynes and White were not far apart on the principle that capital flows might need to be regulated, although Keynes's methods for accomplishing this task were more realistic and therefore much more dirigiste.

This shared tolerant attitude toward capital-account prohibitions was fully reflected in the eventual Articles of Agreement establishing the IMF. A major goal of the IMF system was nondiscriminatory multilateral convertibility on current account (as set out in Article VIII). But Article VI (3) stated that "Members may exercise such controls as are necessary to regulate international capital movements..." Article VI (1) prohibited members from using Fund resources "to meet a large or sustained outflow of capital," and even empowered the Fund to request imposition of capital controls in such cases (Horsefield 1969, pp. 193-94). Keynes's plan had also included the latter feature. ${ }^{39}$

The United States' agreement to such provisions in 1944 and 1945 may seem contrary to its natural interests as the premier creditor and financial power of the postwar period. As noted above, however, Congress was concerned about the extent of America's financial commitment. The allowed restrictions, anyway, seemed unlikely ever to be needed by the U.S., would likely apply to other countries' outflows rather than inflows, and could only ensure New York's position as the world's leading financial center. Business 
interests in the United States were in any case more concerned with currentaccount convertibility and expanded export opportunities than with capital flows.

Moreover, New Deal Washington viewed the financial world with considcrable distrust. This distrust was inherent in the Democratic Party's Jacksonian tradition. But it was greatly heightened by the perceived role of banks and security markets in bringing on the Great Depression. Disillusion with banks and financial markets prevailed in many countries, in fact, and led to a general reduction during the 1930s of central-bank independence in favor of treasury dominance. (See Dam 1982, p. 53. On the United States, see the chapter by Calomiris and Wheelock in this volume.) This view provoked stricter regulations on financial markets in the 1930s. It is also reflected in Treasury Secretary Henry Morgenthau's pronouncement at Bretton Woods that the new institutions would "drive...the usurious money lenders from the temple of international finance" (Gardner 1980, p. xix), and in his successor, Fred Vinson's, unilateral shift of Fund and Bank headquarters from New York to Washington on the purported grounds that "the institutions would be fatally prejudiced in American opinion if they were placed in New York, since they would then come under the taint of 'international finance'." (Keynes 1980a, p. 211). White himself undoubtedly shared these views, arguing in his plan that capital controls "would constitute another restriction on the property rights of the 5 or 10 percent of persons in foreign countries who have enough wealth or income to keep or invest some of it abroad, but a restriction that presumably would be exercised in the interests of the people - at least so far as the government is competent to judge that interest." (Horsefield 1969, p. 67). ${ }^{40}$

\subsection{Postwar Inconvertibility and the European Payments Union}

At the height of the world war in 1943, the governments-in-exile of the Belgium-Luxembourg union and the Netherlands entered into a bilateral financial agreement which was the first of about 200 that would be in effect in Europe by 1947 and nearly 400 that would be in effect worldwide shortly thereafter (Yeager 1976, p. 407). Under the agreement, the two countries promised to peg their mutual exchange rate by standing ready to 
purchase the other's currency. This type of agreement aimed at conserving reserves of hard currency and gold through mutual credit arrangements, but in practice entailed controls over resident transactions so as to prevent the buildup of unbalanced positions in partner currencies. A corollary of hard-currency scarcity was a continuation of currency inconvertibility and of wartime prohibitions on private capital movements, which might quickly strip a government of reserves. Domestic financial controls further limited international intermediation, and, along with the economic and political instabilities implied by reconstruction, blocked the channels through which potential capital-receiving countries might have borrowed privately abroad. Private international capital movements had essentially dried up.

Currency inconvertibility seriously compromised even the gains from current international trade. If country $A$ had a trade surplus with country $B$, it could not use its surplus accumulation of $B$ 's currency to finance a deficit with country $C$, as would have been possible under general external currency convertibility. Somehow, country $A$ 's payments would have to be balanced vis-à-vis both $B$ and $C$ individually, not simply vis- $\dot{a}$-vis the rest of the world taken in totality. Bilateral trading agreements may have been superior to blanket, indiscriminate limitations on foreign transactions in allowing for mutual credits (the trade creation aspect) but they had the drawback of shunting demand from the cheapest source of supply worldwide toward countries with extensive demands for domestic products (trade diversion). A system of multilateral clearing held out the potential of easing such constraints and promoting a more efficient global resource allocation, if only a true multilateral payments system could be attained.

Unfortunately, universal convertibility, even limited external convertibility, was difficult for individual countries to attain in the immediate postwar circumstances. Restoring convertibility required countries to solve a serious coordination problem. In a setting of general inconvertibility, a single country allowing foreigners to freely convert its currency would face an uncomfortable net drain of foreign-exchange reserves: foreign exporters would convert the bulk of their domestic currency earnings into central-bank foreign reserves, whereas most of the foreign currency earned by domestic exporters would be: unusable. The latter could insist on being paid in their own currency, but this would seriously injure sales, as the home country would likely have its best potential export markets in countries from which it did not itself import much. 
Furthermore, foreign countries might deliberately restrict imports from the convertible-currency country so as to maximize their hard-currency inflow at its expense. ${ }^{41}$ Of course, one solution to the problem would have been for monetary authorities simply to refrain from trading domestic currency for foreign currencies, i.e., to let the exchange rate of domestic currency float, as did several countries after World War I. Indeed, Friedman's celebrated polemic "The Case for Flexible Exchange Rates," drafted in 1950, explicitly promoted floating rates as a strategy for moving immediately to general currency convertibility (Friedman 1953, p. 158). This step governments were reluctant to take, out of fear of the currency instability and hyperinflation associated with interwar floating exchange rates.

Article VIII of the IMF Articles of Agreement, as noted earlier, called for convertibility on current account and unrestricted freedom of current international payments. Article XIV, however, allowed countries to maintain restrictions contravening Article VIII during a transitional period, and even to introduce new restrictions. Only five years after the start of IMF operations was any member not yet in compliance with Article VIII required to begin annual consultations on its progress with the Fund.

At the time the Articles were drafted, a five-year breathing space was regarded as allowing a reasonable period for the general return to (currentaccount) convertibility. Nothing of the sort happened. Instead, controls generally proliferated. By 1953, more countries were engaging in multiple currency practices than in 1946 , leading Mikesell (1954, pp. 25-7) to the exasperated remark that "the system of fixed exchange parities combined with a complex of neo-Schachtian devices has provided far less exchange stability in the postwar period than did the fluctuating free exchange rates of the 1930s." By 1957, only eight countries apart from the U.S. and Canada Mexico, Cuba, the Dominican Republic, Guatemala, El Salvador, Honduras, Haiti, and Panama - had formally accepted the Article VIII obligations (Triffin 1957, p. 115). The proliferation of controls reflected the same forces preventing unilateral movements toward convertibility by dollar-hungry countries. A classic example is that of Switzerland, which, to protect foreign exchange reserves, made its franc inconvertible for Europeans while leaving it convertible for residents of the dollar area. ${ }^{42}$

Some countries responded to the situation by adopting floating exchange rates, IMF norms notwithstanding. Canada dismantled its exchange con- 
trols under cover of a floating rate, Mexico, Peru, and Chile likewise floated their currencies, and Churchill's government in Britain seriously debated a scheme for freeing the pound in 1952 (Cairncross 1985, chap. 9; Kaplan and Schleiminger 1989, chap. 10).

Triffin argued that the IMF might have been able to move the world more quickly to convertibility if its structure had facilitated multilateral clearing, for example through Keynes's conception of a synthetic international currency. Instead, the Fund blueprint "dealt with the setting up and revision of par values, the elimination of exchange controls, and the Fund's lending operations as if these problems could be handled with each country individually against a background of general convertibility and stability in world trade and currency arrangements" (Triffin 1957, p. 137). The coordination problem involved in moving to the latter type of equilibrium from the one left by the war was not addressed.

The hazards of a unilateral return to convertibility by war-torn countries are well illustrated by Britain's abortive attempt to restore multilateral current-account convertibility for sterling in July 1947-an experiment that had to be abandoned after only five weeks. In September 1945 a British delegation led by Keynes arrived in Washington to negotiate a loan of dollar reserves. The United States insisted (among other conditions) that sterling's convertibility on current account be restored no later than one year after the funds (totalling $\$ 3.75$ billion) became available. Congress and American business interests strongly supported the convertibility provision (as well as an associated trade nondiscrimination clause; see Gardner 1980, pp. 197-98). In particular, these groups felt that the IMF Articles' timetable for restoring convertibility was lax. Immediate convertibility of so widely-held a currency as sterling, it was believed, would hasten worldwide freedom of current payments, at the same time easing discriminatory trade practices intended to maximize bilateral trade surpluses with the U.S.

Britain put aside its misgivings and agreed to these terms. July 15, 1947 emerged as sterling's convertibility date after congressional approval of the loan midway through $1946 .{ }^{43}$ Britain's current-account deficit increased sharply after the harsh winter of 1946-47. By the end of June more than half the U.S. loan had been used up (Cairncross 1985, p. 132). Despite continuing gold and dollar outflows, however, Britain fulfilled its commitment and declared convertibility on July 15 , hoping desperately that convertibility 
would raise global confidence in sterling. Instead reserve outflows accelerated. With only $\$ 400$ million of the American loan remaining, Britain suspended convertibility on August 20.

The sharp acceleration in dollar losses in July seems largely to have been the result of capital outflows. It was feared that convertibility would be fleeting and that sterling might be devalued once the experiment failed. Now was the time to get dollars, and at a relatively cheap sterling price. (Convertibility did turn out to be very temporary, but the feared devaluation didn't come until 1949.) The result was a classic speculative attack. How was an attack on sterling carried out in a world of seemingly pervasive capital controls? Some countries converted preexisting sterling balances into dollars, representing them as current earnings. On the basis of revised balance of payments data Cairncross (1985, p. 157) argues that this channel was not very important, notwithstanding a long tradition placing much of the blame for the debacle on such conversions (for example, Gardner 1980, pp. 31718). More significant were "leads and lags" in trade credits-the practice of accelerating sterling payments and delaying foreign-currency receipts in the expectation of a sterling depreciation (Einzig 1968). Finally, some reserves leaked out through capital transfers to other Sterling Area countries. Sterling Area members such as South Africa and Australia borrowed large sums of sterling in London and rapidly used the proceeds for imports from the dollar area. $^{44}$

The crisis carried two distinct lessons. First, in the circumstances of the immediate postwar years, a single country like Britain with a structural current-account deficit due to wartime changes could not unilaterally return to convertibility. Any such return would need to be coordinated among many nations. As Gardner puts it:

The fact is that the negotiators [of the Anglo-American loan agreement] did not fully understand the economics of convertibility. They did not appreciate the difficulty in which Britain might find itself in the event that it went on accumulating inconvertible currencies while other countries, deliberately restricting imports from the United Kingdom, presented large sterling surpluses for conversion. Given this hazard of making one currency convertible in a generally inconvertible world, the use of a rigid time-table was certainly injudicious. (Gardner 1980, p. 218) 
A second lesson of the crisis, one less appreciated at the time, was that damaging speculative crises could occur even under exchange control. Capital controls were porous, certainly porous enough to devastate the slim liquidity bases upon which most countries were operating in the late 1940s. The channels of capital flight revealed in the U.K. convertibility crisis, especially leads and lags, would remain widely operative through the end of the Bretton Woods system, coming strongly into play whenever the prospect of devaluation offered a large speculative gain over a short period. Indeed, the scope for such phenomena only increased as trade expanded in the 1960s.

Even before Britain suspended sterling's short-lived convertibility, the United States proposed the Marshall Plan with its accompanying call for economic cooperation within Europe. The Plan reflected a change in the U.S. "universalist" approach to postwar economic problems, motivated by the perception of a dire political threat to a uniquely important region. American policymakers had hoped that Marshall aid would promote intra-European trade, strengthening Europe's economies and creating a shared interest in political stability. However, the absence of any multilateral clearing system for intra-European payments frustrated this hope. Under prodding from the U.S. European Cooperation Administration, which had been set up to administer the Marshall funds, the nations of western Europe in September 1950 created the European Payments Union (EPU). The EPU was a major success in facilitating trade liberalization within Europe (as well as within territories on other continents that belonged to some European country's currency area). The EPU worked by each month consolidating each member's bilateral payments deficits into a net debt to the Union, extending some credit but eventually requiring settlement in dollars and gold. This arrangement allowed European country $A$ to use its surplus with European country $B$ to finance its deficit with European country $C$, despite the inconvertibility of $B$ 's currency. (The IMF, in contrast, could perform no comparable clearinghouse function. $)^{45}$

The initial success of the EPU allowed some privatization of foreign exchange transactions, which had been concentrated in the hands of central banks. This liberalization allowed private banks to take over some of the EPU's clearing functions. Over the course of the 1950s several EPU members, notably the United Kingdom and Germany, liberalized foreign exchange transactions further, Germany going much furthest in allowing residents to 
retain foreign-exchange earnings and to hold foreign assets. (In the U.K., residents could deal among themselves in a managed pool of foreign "investment currency" but otherwise were barred from acquiring foreign assets, while nonresidents until 1967 had to trade sterling securities in a separate market for "security sterling.") During 1957-58 Europe's hard-currency reserves rose sharply, the counterpart of a huge U.S. payments deficit. On December 27, 1958, the EPU was terminated by mutual consent, with most members, including France, Germany, Italy, and the United Kingdom, declaring their currencies externally convertible on current account. (The former EPU countries formally accepted their Article VIII convertibility obligations in February 1961. Japan followed in April 1964.) Germany also moved to full convertibility on capital account, so that, as of January 1959 the Bundesbank could declare that

only the payment of interest on foreigners' balances, the sale of domestic money-market paper to foreigners and the taking of foreign loans running less than five years remain forbidden, the object being to check the inflow of "hot money" into the Federal Republic (Deutsche Bundesbank 1959, p. 52).

Germany's motives for such wide-ranging liberalization were two. One was the free-market ideology characteristic of Economics Minister Ludwig Erhard's policies. Equally important, however, was the pressure on Germany's internal liquidity and prices due to the chronic balance of payments surplus that had developed after the early 1950s. By liberalizing capital outflows, the authorities hoped to reduce the payments surplus, whereas the remaining capital controls listed in the preceding quotation were intended to discourage capital inflows and provide scope for sterilization operations. ${ }^{46}$

In 1957 Belgium, France, Germany, Italy, Luxembourg, and the Netherlands signed the Treaty of Rome creating the European Economic Community (EEC). The Treaty called on signatories to undertake the progressive abolition "between themselves of all restrictions on the movement of capital belonging to persons resident in Member States..." (Article 67 (1), quoted in Bakker 1996, p. 279). This provision was viewed as fundamental to the longterm goal of a single European market. The EEC ECOFIN Council's first directive of May 1960 required member countries to free short-to-medium term trade credits, direct investments, and cross-border trades of listed shares. 
Germany had pushed for full liberalization of capital movements in the negotiations leading to the directive, including movements between EEC members and nonmember states (Bakker 1996, p. 81). In May 1959, seeing a welcome fall in its official reserves and assuming that the policy of encouraging capital exports was working, Germany unilaterally abolished its remaining restrictions on capital import (Yeager 1976, p. 496). Despite policymakers' optimism, however, Germany was very shortly to experience the type of policy conflict that ultimately brought the Bretton Woods system down amid escalating capital controls.

\subsection{The Collapse of Bretton Woods}

Only the month after the EEC ECOFIN Council's directive on liberalization of capital movements, Germany reimposed some of the controls it had abolished a year earlier, hoping to discourage renewed capital flows. Attempting to restrain a domestic boom through higher interest rates, the Bundesbank found itself frustrated by the large volume of reserves purchases it was obliged to carry out to maintain the Deutsche mark's exchange parity. In March 1961, Germany, soon followed by the Netherlands, reluctantly revalued its currency by 5 percent against the dollar.

These events heralded a new era in which speculative capital flows continually bedeviled policymakers in Europe and elsewhere. Concerted EEC progress on further capital-account liberalization bogged down, and fear of speculation made any open discussion of exchange parity changes impossible. Italy suffered a balance-of-payments crises in 1964, which it beat back with the help of loans from the U.S. and the IMF. Britain entered a prolonged period of crisis in the same year, giving in finally and devaluing sterling in November 1967. Nonetheless, individual European countries did take some liberalizing steps in the early and mid-1960s. Italy allowed its residents more freedom to invest abroad. France, enjoying a strong balance of payments during the mid-1960s, unilaterally eased its controls in 1967, motivated in part by a desire to promote the role of Paris as a global financial center (Bakker 1996, p. 101). However, the May 1968 disturbances sparked capital flight and a reimposition of French controls; at the same time Germany, the recipient of much of the flight capital tightened its own barriers to capital inflows. Speculation contimued into 1969: France resisted until the specula- 
tion temporarily subsided, then surprised markets by devaluing in August. Speculation on a German revaluation reemerged in the same year in advance of parliamentary elections. Just prior to the election, the government closed the official foreign exchange market, then allowed the Deutsche mark to float. The new government of Chancellor Willy Brandt revalued the currency by just over 9 percent at the end of October.

How could capital flows continue to undermine authorities' efforts to defend exchange parities even in the face of tightened capital controls? Leads and lags in trade credits again provided an important conduit for speculative capital flows; indeed, Einzig (1968) characterized leads and lags as "the main cause of devaluation" in his book on the subject, although his broad definition of the phenomenon included changes in the timing of goods orders (not just payments) as well as forward currency trades. The growth of international trade after the early $1950 \mathrm{~s}$ in itself a prime desideratum of the Bretton Woods architects--ironically expanded the opportunities for disguised capital flows. The reopening of private foreign exchange markets and the emergence of the Eurocurrency markets in London in the 1960s further widened the scope for leakages from protected domestic financial systems. The growing tendency to delay realignments until the market forced the authorities' hand, itself a result of increasing possibilities for speculation, ensured that a speculative attack might produce very large profits over a very brief period. Thus, even modest elasticities of trade credits, say, with respect to normal interest differentials, could translate into large flows of reserves in crisis episodes.

The United States meanwhile had been facing its own problems since the end of the period of "dollar shortage" in the late 1950s. Growing U.S. balance-of-payments deficits were causing alarm. The counterpart of these deficits was a growing stock of short-term official dollar claims on the U.S. Some of these claims were converted into gold, putting pressure on the American gold stock, but the bulk were held despite mounting anxiety that the dollar's gold content might suddenly be reduced. In response, the U.S. took a number of measures to counter private capital outflows. Starting in 1961, an escalating sequence of dividend and interest taxes, voluntary guidelines, and mandatory limits were imposed on American capital outflows abroad (see Bordo 1993, p. 58; Solomon 1982, chaps. 3 and 6.). The ultimate effectiveness of these measures remains debatable even today. For example, 
New York banks, restricted from lending directly to foreigners, could legally set up London subsidiaries capable of taking dollar deposits and making the forbidden loans. Non-U.S. banks also competed for this business. Regulations meant to retain dollar inflows within U.S. borders therefore shunted these dollars into the London Eurodollar market, promoting that market's spectacular growth at the expense of onshore U.S. banks. ${ }^{47}$

The dollar itself came under concerted attack in the early 1970s, a development due in part to President Lyndon Johnson's escalation of military and domestic spending, in part to divergent productivity trends. Increasingly volatile capital flows set the stage for the ultimate collapse of fixed exchange rates in early 1973 (see Solomon 1982, chaps. 11-13; Yeager 1976. chap. 28). Several industrialized countries temporarily floated their currencies prior to the Smithsonian dollar devaluation of December 1971 and several, including Germany, imposed restrictions on capital inflows (Bakker 1996, p. 122). When the new Smithsonian parities were attacked over 1972 and 1973, Japan, Switzerland, Germany, France, and the Netherlands all raised their barriers to capital inflows, including quantitative borrowing restrictions, interest taxes, and supplemental reserve requirements. Concerned by the disruptive effect of floating intra-European exchange rates on its common agricultural policy and on its ongoing drive for further economic integration, the European Community (EC) issued a general derogation from its May 1960 first directive on capital-account liberalization, and went further in directing members to develop or reinstate effective mechanisms for controlling capital flows and their effects on domestic money supplies (Bakker 1996 , pp. 116-18). The lira and sterling, like the dollar, were under selling pressure; Italy and Britain raised barriers to stem outflows as a result. In June 1972 the U.K. extended its exchange control system to apply to transactions within the Sterling Area, and let the pound float downward. The pressure of speculation remained unbearable however. By March 1973, industrialized country currencies were floating against the U.S. dollar, with six EEC currencies floating jointly within a "snake" while Italy and the Anglo-Irish currency union floated independently. 


\subsection{The Process of International Financial Integration after 1973}

Bretton Woods proved untenable in the end because its rules could not reconcile independent national policy goals, pegged exchange rates, and even the limited degree of capital mobility implied by an open world trading system. Once industrial countries had been forced to accept floating dollar exchange rates as an open-ended interim regime, however, at least some governments felt free to liberalize capital movements without sacrificing either their domestic policy priorities or an external currency commitment. Over the years 1974 to 1975, the U.S. dropped its restrictions on capital outflows while Germany liberalized inflows. Germany would again deploy controls over inflows in the late 1970s when dollar weakness threatened to enhance the reservecurrency status of the Deutsche mark, a development the Bundesbank has resisted.

France and Italy retained and even tightened some controls in order to loosen the link between monetary and exchange-rate policy. A strong motivation for these actions was the desire to limit intra-EC exchange rate fluc-

tuations, first within the informal EC currency snake and later within the European Monetary System (EMS) (Giavazzi and Giovannini 1989; Bakker 1996). The United Kingdom also tightened and retained controls until 1979. In that year, Thatcherite free-market ideology, allied with a fear that North Sea Oil would bring the "Dutch disease" of sterling appreciation, together led to suspension of the 1947 Exchange Control Act, and full capital-account liberalization. Japan largely opened its capital account in December 1980, the culmination of a series of steps beginning in 1974. Liberalization was typically undertaken to promote inflows or outflows that would counter yen depreciation or appreciation; only rarely were controls tightened. The liberalizing trend seems to have reflected pressures from the domestic business and financial community (Ito 1992, pp. 316-21). Further measures to ease foreign asset exchanges were taken in 1984, partly as a result of United States pressure (Frankel 1984; Ito 1992, p. 329).

Developing countries almost universally retained tight capital-account controls throughout the entire Bretton Woods periods, the most important sources of capital inflow being official loans and foreign direct investment. The two oil-price shocks of the 1970s produced large and persistent surpluses for oil producers but only transitory deficits for the industrialized 
world. The oil surpluses were "recycled" to developing countries through industrialized-country banks, so that by the early 1980s developing market borrowers owed a substantial debt to the banks, most of it government or government-guaranteed. Most developing countries retained strict control over private exchange transactions. As of April 30, 1980, only 50 of 140 IMF members had formally ceased operating under the "temporary" Article XIV derogation of Article VIII (Dam 1980, p. 101), although these countries accounted for most of world trade.

The developing-country debt buildup turned into a crisis in August 1982 under the pressure of a global economic downturn and sharply higher world interest rates. Bank lenders became unwilling to extend new loans or even roll over maturing debts, and generalized default loomed, as in 1931. Open default was avoided through concerted rescheduling orchestrated largely by the United States and the IMF. Only toward the end of the 1980s did U.S.brokered debt workouts under the Brady plan begin to pave the way for renewed private lending to the developing world, which boomed in the early 1990s. Direct investment has grown significantly, but more strikingly, bank lending to governments has given way to portfolio investment in bond and equity markets (see Table 4.1). The shift in the composition of developingcountry liabilities is in part a reflection of wide-ranging financial-sector restructuring in these countries.

In the mid-1970s several Latin American countries, notably Argentina, Chile, and Uruguay, opened their capital accounts as part of exchange-rate based stabilization programs. These programs, flawed by insufficient fiscal stringency, inadequate domestic financial supervision, and inconsistent wage indexation structures, all proved to be unsustainable, and were followed by renewed capital-account restrictions. More recently, numerous developing countries in East Asia have instituted domestic financial deregulation and at least partial capital-account opening, often in the face of large external surpluses. Similar developments followed in Latin America against a background of serious fiscal reform, aggressive privatization, and successful inflation stabilization. ${ }^{48}$ These reform efforts encouraged renewed capital inflows, although the decline in U.S. interest rates in the early 1990s is clearly an important additional causal factor. Two closely interrelated issues of debate, as yet unresolved, are the appropriate degree and form of exchange-rate flexibility and capital-account control for these countries. 
Table 4.1

Net Capital Flows to Developing Countries, 1977-94

Billions of U.S. dollars

\begin{tabular}{lrrr}
\hline Category of Capital Inflow & $1977-82$ & $1983-89$ & $1990-94$ \\
\hline Foreign Direct Investment & 11.2 & 13.3 & 39.1 \\
Portfolio Investment & -10.5 & 6.5 & 43.6 \\
Other (Including Bank Lending) & 29.8 & -11.0 & 22.2 \\
\hline Total & 30.5 & 8.8 & 104.9 \\
\hline
\end{tabular}

Notes: See text.

Source: Folkerts-Landau and Ito (1995, p. 33). 
The durability of the developing world's return to the global capital market remains to be seen. Investor interest weakened when U.S. interest rates rose in 1994, and several industrializing countries faced pressure in the aftermath of the 1994-95 Mexican crisis. Markets have so far displayed greater resilience than in 1982; even Mexico has been able to borrow again, albeit with the aid of extraordinary financial backing from the United States Treasury and the IMF.

Perhaps the most dramatic move toward full capital-account liberalization occurred among the continental members of the European Union (EU). Starting in the early 1980s, these countries began moving toward the goal of free intra-European capital mobility foreshadowed in the Treaty of Romewhich in practice implied unrestricted mobility vis-à-vis the outside world as well, given Germany's commitment to openness and the difficulty in any case of enforcing partial restrictions. France joined the trend after 1983, when President François Mitterand abandoned his socialist growth agenda in favor of the franc's continued participation in the EMS exchange-rate mechanism. Germany has consistently pushed its European partners toward capital-account freedom, except while Bretton Woods was unraveling in the early 1970s. An important motive for this advocacy has been the belief that an open capital account would impose discipline over monetary and fiscal policies. Germany's capital account was completely open by 1981, that of the Netherlands by 1986, Denmark's by 1989, Belgium-Luxembourg's and Italy's by 1990, Spain's, Portugal's, and Ireland's by 1992, and Greece's by 1994 (Bakker 1996, p. 220). Austria, Sweden, and Finland, which joined the EU in 1995, also had open capital accounts of fairly long standing by that time.

Driving this broad liberalization was an acceleration in both commoditymarket integration within Europe and in plans for monetary union. The EMS currency crisis of the years 1992 to 1993 illustrated once again the untenability of fixed exchange parities when capital is mobile and domestic economic conditions assume primacy over the exchange rate. However, calls to reinstate capital controls after the crises of the early 1990s have so far been rejected, and the EU remains committed in theory to full monetary and financial integration by January 1,1999 . If that momentous event comes to pass, even on the limited basis of a small core of countries including France and Germany, the utopian goal of European economic union first espoused by 
the United States in the late 1940s will be substantially achieved. As of this writing (early 1997), that goal once again appears to coexist uneasily with internal political realities. Indeed, the current drive by EU governments to meet the Maastricht macroeconomic convergence criteria has allowed some degree of exchange stability, but at the cost of rising unemployment. These recent developments are uncomfortably reminiscent of the coordinated global macro policy contraction that brought on the Great Depression. Happily, most of the world is not participating this time.

\section{Summary}

This paper has chronicled both the decline of the international capital market in the Great Depression and its gradual regeneration over the period since the second World War. A major unifying theme in that story has been the basic incompatibility of open capital markets with a regime that aims to attain both exchange-rate stability and domestic employment or growth objectives. Under the gold standard before 1914, exchange stability was the overriding goal of monetary policy and domestic objectives took a back seat. Thus, the monetary regime was consistent with considerable international capital mobility. The Great Depression discredited gold-standard orthodoxy, propelled Keynesian economics to intellectual ascendancy, and, worldwide, solidified the already vocal political constituencies favoring high employment and government intervention over laissez-faire. The result was a postwar international monetary system based on capital-account restrictions and pegged but adjustable exchange rates, one whose very success ultimately led to increasingly unmanageable speculative flows and floating dollar exchange rates among the industrialized economies. Floating rates, in turn, have allowed the industrialized countries to deregulate capital flows extensively while pursuing domestic macro goals. In the European Union, where capital mobility is free, the tension between domestic political imperatives and the supranational goal of monetary union remains apparent only two years before the January 1, 1999 deadline for a single EU currency laid down by the Maastricht Treaty. In the developing world, there is continuing experimentation and debate over the optimal point on the tradeoff among currency stability, freedom of capital movements, and other economic goals.

Domestic financial deregulation, like capital-account decontrol, also ac- 
celerated in the 1970s. In part that development flows from the trend toward freer international financial trade. After the $1950 \mathrm{~s}$, countries increasingly allowed home-grown financial institutions to compete for international business within enclaves separated from domestic markets by a strict cordon sanitaire. As resident capital controls were lifted, however, domestic deregulation became a competitive necessity. Domestic deregulation and the consequent growth of the financial sector, in turn, have made it much harder to reimpose capital-account restrictions effectively today. The potential threat to systemic stability that competitive financial deregulation poses has motivated the Basle Committee's work since 1974 on supervisory collaboration among nations.

At the start of the Great Depression the United States was the dominant economic power in world markets, but had no appetite for a commensurate political leadership role. Even before World War II had ended the U.S. government recognized America's natural position of leadership and implemented several strategies to further a vision of a cooperative postwar international economic order. In the 1990s major components of that vision have largely been realized, though not within a policy regime the American postwar planners would recognize or, most probably, endorse. While the current system is not free of shortcomings, it has allowed sovereign nations to coexist and, where they have liberalized and opened their economies, to begin converging. Moreover, a replay of the Great Depression has been avoided so far. It is ironic that the current international system sprung directly from one based on disillusion with the interwar performance of free capital mobility and floating exchange rates alike. Thus Keynes's remark in closing the Bretton Woods conference may still be appropriate (Keynes 1980b, p. 103): "How much better that our projects should begin in disillusion than that they should end in it!" 


\section{Endnotes}

1. Our interpretation is consistent with the view in the political science literature that purposeful government control is the key factor determining the degree of international financial integration. See, for example, Helleiner (1994) and Kapstein (1994), and the references they list. Also relevant to our analysis is the paper by Epstein and Schor (1992), who link the existence of controls to the balance of power between labor-oriented interests favoring Keynesian macroeconomic policies and financial-oriented interests favoring inflation containment. We stop short in this paper of a formal econometric analysis of the determinants of capital controls. Alesina, Grilli, and MilesiFerretti (1994) and Grilli and Milesi-Ferretti (1995) carry out panel studies of the incidence of capital controls (for 20 industrial countries over the years 1950 to 1989, and for 61 industrial and developing countries over the years 1966 to 1989). Consistent with our interpretation, they find that more flexible exchange rate regimes and greater central bank independence lower the probability of capital controls. In their chapter in this volume, Bordo and Eichengreen discuss these results in greater detail and reconsider the effects of postwar capital controls on macroeconomic outcomes.

2. Formally, we make definitions as follows. GNP is given by $Y=Q+r B=$ $C+I+G+N X+r B$, where $Q$ is GDP, $C$ is private consumption, $I$ is investment, $G$ is public consumption, $N X$ is net exports, and $r$ is the return on net foreign assets $B$. The current account $C A$ satisfies $C A \equiv N X+r B=$ $(Y-C-G)-I=S-I$, where $S \equiv Y-C-G$ is national saving. Finally, note that the dynamic structure of the current account and the external credit position is given by the equality of the current account surplus $(C A)$ and the capital account deficit $(-K A)$, so that $B_{t+1}-B_{t} \equiv-K A_{t}=C A_{t}$.

3. The open circles in Figure 2.1 and in Figure 2.3 (below) denote gaps in data coverage due to the two world wars. The circles' positions are determined by the incomplete sample of countries for which data are available.

4. In that era the main lender was Britain, whose current account surplus was often in the range of 5\%-10\% of GDP (Edelstein 1982).

5. Eichengreen (1991) presents similar data for the interwar period, as does Marston (1995) for the postwar period. Under a fixed exchange rate regime such as the gold standard, another arbitrage-like test of financial-market integration asks whether nominal interest differentials in different currencies are consistent with the maximal allowable exchange-rate fluctuation band (Goschen 1861; Weill 1903; Morgenstern 1959; Officer 1996). Such a test 
relies on the maintained hypothesis that the exchange-rate band is credible (though not on uncovered interest parity), and more recently has been interpreted as a test of exchange-rate credibility (Svensson 1991; Giovannini 1993; Marston 1995, chap. 5; Hallwood, MacDonald, and Marsh 1996).

6. This arbitrage argument underlies the calculation in the textbook by Spalding (1915, chaps. 5-6), for example, although he assumes perfect international financial integration. Notice that, unlike in the case of covered interest. arbitrage, differential default risk between the New York and London markets is not important here. An implicit forward exchange rate based on the so-called "long" exchange rate $b_{t}$ is given by $f_{t}^{\text {implicit }}=b_{t}\left(1+i_{t}\right)$.

7. The data were collected from various sources. Exchange rates: Before 1921 spot and sixty-day sterling bill exchange rates (in U.S. dollars) are from the Financial Review or Commercial and Financial Chronicle; 1921-1936 spot and ninety-day forward rates are from Einzig (1937), 1937-November 1946 spot and ninety-day forward rates are from the Economist, December 1946-May 1947 spot and thirty-day forward rates are from the Wall Street Journal, June 1947-1965 spot and ninety-day forward rates are from the New York Times, and thereafter from OECD Historical Statistics and (starting in January 1976) from Reuters (as reported by Datastream). The Einzig foreign exchange data are monthly averages whereas all other exchange rates are taken at or near the end of the month. Interest rates: From 18701920, three month rates on London bank bills from Capie and Weber (1985), data taken at or near end of month. From 1921-1936, month average data on London and New York three-month market discount rates from Einzig (1937). United Kingdom interest rate data for 1937-April 1971 are threemonth London bank bill rates from Capie and Weber (1985); from May 1971April 1991, three-month London bank bill rates from Datastream; and from May 1991-April 1996 five-month London bank bill rates from Datastream (all at or near end of month). From 1937-April 1940, rates on banker's acceptances in New York from the Economist, at or near end of month. From May 1940- May 1947, the same rates are monthly averages as reported by the Federal Reserve. From June 1947-1965, 30-to-90 day banker's acceptance interest rates in New York come from the New York Times, observed at or near month's end. Data for January-April 1966 are month averages of 90day banker's acceptance rates reported by the Federal Reserve. Starting in May 1966 the Fed reports month-end data, which we have used in the calculations.

8. The rather stable premium on New York loans before World War I (which 
appears to fall in the early twentieth century) probably reflects a less liquid market, as well as perceptions of repayment risk. (The London reference rate is a high-quality bank bill rate.) For a comparative discussion of the New York and London capital markets before 1914, see Davis and Cull (1994, chap. 4).

9. Uncovered (or "open") interest parity requires that the expected rate of relative currency depreciation over the relevant horizon equal the corresponding nominal interest rate difference between the two currencies,

$$
\mathrm{E}_{t} e_{t+1}-e_{t}=i_{t}-i_{t}^{*} \text {. }
$$

Here $e_{t}$ is again the log spot exchange rate (defined as the domestic-currency price of foreign currency) and $i_{t}$ and $i_{t}^{*}$ are the home and foreign currency interest rates. Purchasing power parity (strictly, the Strong Relative version of PPP) implies that expected exchange rate changes equal expected inflation differentials,

$$
\mathrm{E}_{t} e_{t+1}-e_{t}=\mathrm{E}_{t} \pi_{t+1}-\mathrm{E}_{t} \pi_{t+1}^{*},
$$

where $\pi_{t+1}=p_{t+1}-p_{t}$ and $\pi_{t+1}^{*}=p_{t+1}^{*}-p_{t}^{*}$ are the inflation rates in the two currencies based on $\log$ price levels $p_{t}$ and $p_{t}^{*}$. UIP and PPP together imply the equalization of ex ante real interest rates,

$$
r_{t}=i_{t}-\mathrm{E}_{t} \pi_{t+1}=i_{t}^{*}-\mathrm{E}_{t} \pi_{t+1}^{*}=r_{t}^{*} .
$$

(Since UIP compares assets with the same country/political risk characteristics, and which may be freely traded against each other, capital mobility comes in by ensuring that interest rates on a given currency are the same the world over, as discussed in section 1.3.)

10. Transport costs or regulations impeding the international shipment of tradables will, however, weaken any tendency for countries' price levels to converge.

11. The method echoes the recent study of Lothian (1995), and we find similar patterns here. Eichengreen (1991) compares and analyzes real interest differentials over subperiods of the interwar period.

12. The British government, for revenue reasons, also levied a stamp tax on foreign bearer bonds. See Moggridge (1971), who concludes, however, that British government suasion over foreign lending was largely ineffective in 
keeping capital at home, and that the stamp tax could be evaded. His conclusion receives support from Figure 2.2, which shows that from 1924 through 1930, sterling interest rates in London frequently exceeded the covered sterling return on New York loans.

13. It was during a brief period in 1919 that Joseph A. Schumpeter served as Austrian finance minister. He favored a capital levy.

14. In many ways the direct and indirect measures are interchangeable as policy instruments. Differential exchange rates according to type of good may yield the same relative price structure as a tariff schedule. Barter arrangements in trade resemble the outcome of a strict bilateral exchange clearing arrangement. Thus, although direct measures impinge directly on foreign capital movements, so too do the indirect measures.

15. Bratter (1939, p. 274) again: "In effect control of the volume of foreign exchange transactions with foreign countries amounts to determination of the value or volume of goods and services exchanged with foreign countries. Exchange control accomplishes the purpose of a protective tariff or an import embargo. And it has the further 'advantage' that it often operates secretly as to the details."

16. Kindleberger $(1984$, p. 392$)$ notes the very desperate measures favored in fascist Germany and Italy, where punishments continuously increased in severity until they included the death penalty in both countries.

17. Stewart (1938, p. 57) noted: "There is, first of all, complete freedom of transferring pounds sterling into foreign currencies and, secondly, there are ample facilities for the purchase in London of foreign securities. The inconsistency of keeping these channels open while maintaining a strict embargo on new foreign issues has been severely criticised."

18. Italy's controls were "so stringent as to render her gold bloc status meaningless" (Eichengreen 1992b, p. 357). The Belgian controls admitted loopholes, and were rendered immaterial within weeks as speculators, anticipating a devaluation, provoked one (Eichengreen 1992b, pp. 362-63).

19. This payment was an option typically more injurious to the creditor than even a temporary moratorium - a suspension which might only for a time prevent the discharge of debts, but which did not inflict any change in the final terms of settlement.

20. Put another way, the banks treated the accounts as reserves, rather than as earmarked funds not strictly available. 
21. Discounts were low for countries whose exports commanded a return, but very high for currencies whose only use was for very unattractive direct foreign investment in the debtor country.

22. Absurd examples of trade diversion included the imports of raw materials in a bilateral clearing deal, and subsequent reexport at a large loss to a freecurrency country, undercutting the original producer, simply as a means for the re-exporter to obtain foreign exchange (League of Nations 1938, p. 35).

23. The discovery that such policies could radically alter the shape of foreign trade and the level of domestic economic activity eventually allowed new and broader purposes of economic control to motivate the use of exchange control, beyond the presumably temporary intent to manage transitory payments crises. It was partly thus that "reactive" policies of the 1930 s paved the way for a transition to import substitution strategies in the 1940s and 1950s. See Fishlow (1971) and Díaz Alejandro (1984).

24. Of these, only Venezuela permitted a completely "free" parallel market: other countries intervened to greater or lesser extents. More "passive" countries such as Cuba, the Dominican Republic, Ecuador, El Salvador, Guatemala, Haiti, Mexico, Panama, and Peru did not institute any controls in the 1930s (Bratter 1939, pp. 280-81).

25. The methods of exchange control varied. For example, in Argentina, the government still favored allocation of foreign exchange to balance bilateral trade, much to U.S. consternation, and largely a result of the 1933 Roca-Runciman treaty with Britain---itself a deal struck to offset of British imperial trade preferences established in the Ottawa treaty (Bratter 1939, pp. 279-81; Salera 1941). A much stricter regime of controls held sway in Uruguay--four varieties of exchange rate were subject to manipulation, bilateral clearing arrangements were even more constraining, and attempts to favor particular products and trading partners more pervasive (Bratter 1939, pp. 281-82).

26. Between 1929 and 1937, the British shares of imports fell in Brazil (19.2 percent to 12.1 percent), Chile (17.7 percent to 10.9 percent), and Peru (15.0 percent to 10.3 percent), whilst German import shares to all three rose (Brazil: 12.7 percent to 23.9 percent; Chile: 15.5 percent to 26.1 percent; Peru: 10.0 percent to 19.7 percent; all figures from Bratter 1939, p. 284).

27. Equivalently, Eichengreen (1992b, p. 258) uses a three-category classification consisting of "exchange controlled," "Sterling Area," and "Gold Bloc"--in 
practice, those not on controls or pegged to gold chose a Sterling peg, with a few exceptions (for example, Canada, which pegged to a Sterling-dollar basket). After 1935 the gold bloc collapsed. France, Switzerland, and the Netherlands departed from their earlier policies, but without control. Some exchange-control countries did chose to devalue, e.g., Italy, Czechoslovakia, Greece, and some no longer adhered to official rates of exchange. The conclusion of the Tripartite Agreement between Britain, France, and the U.S. lent a modicum of stability and a veneer of cooperation to international monetary arrangements, and conditions improved until the recession of 1937 (League of Nations 1938; Eichengreen 1992b).

28. See, for example, Choudhri and Kochin (1980), Díaz Alejandro (1983), Eichengreen and Sachs (1985), Hamilton (1988), Temin (1989), Campa (1990), Eichengreen (1992b), Bernanke (1995), and Bernanke and Carey (1996). These writers have followed upon a nonformal tradition that quite clearly appreciated the basic monetary forces at work in propagating and prolonging the Depression, but that lacked a rigorous analytical and statistical framework for representing their global scope. Thus, Edward M. Bernstein, Harry Dexter White's deputy at the U.S. Treasury during the Bretton Woods negotiations and the first research director of the IMF, recalled in 1984 that "We [at the Treasury] held that the Great Depression was caused by the interaction of the wartime inflation and the traditional gold standard.... The Great Depression did not end until every country had abandoned the gold parity of its currency..." (Black 1991, p. 98). Sce also Haberler's (1976) evaluation. Eichengreen (1992b) cites Ralph Hawtrey and Lionel Robbins as early precursors. Unfortunately, the insular focus of much American macroeconomic thinking for at least 35 years after World War II tended to blind many U.S. scholars to the powerful international monetary transmission mechanism at work in the Depression.

29. The exchange-control countries in the sample are Argentina, Austria, Czechoslovakia, Denmark, Estonia, Germany, Greece, Hungary, Italy, Japan, Latvia, and Romania The free exchange countries are Australia, Belgium, Canada, Finland, France, Netherlands, New Zealand, Norway, Poland (which imposed controls only in 1936), Spain, Sweden, Switzerland, the United Kingdom, and the United States. (Some countries, such as Argentina, Austria, and Denmark, both devalued early and imposed controls.) WPI data come from League of Nations, World Production and Prices, 1937/38. Industrial production data come from the same source, except for Argentina, Australia, and Switzerland, the data for which are used in Bernanke and Carey (1996) and were generously provided by Ben Bernanke. 
30. The coefficient on CONTROLS in the last regression implies that, on average in the sample, imposing exchange controls nearly offset the negative output effect of not devaluing. This result appears at odds with the conclusion in Table 12.1, column 4, of Eichengreen (1992b, p. 350), that exchange control countries did better than gold bloc countries but much worse than devaluers. However, the exchange control group underlying the last regression is larger than Eichengreen's, including, in addition to his observations, Argentina, Japan, Romania, Greece, Latvia, Estonia, and Denmark.

31. A currency is externally convertible if foreigners who hold it (but not necessarily residents of the issuing country) may exchange it freely for other currencies or for domestic goods and assets. The currency is externally convertible for current transactions if foreigners who have acquired it through exports or receipts of asset income can convert it into other currencies or domestic goods. (In contrast, a currency is internally convertible when domestic residents may freely exchange it for other currencies.) For a discussion of various notions of convertibility, see McKinnon (1979, pp. 3 7).

32. In August, Keynes was placed on the Exchange Control Conference.

33. The Sterling Area's holdings of hard currencies were centralized at the Bank of England, which also supplied these resources when needed by Area members. Both internally and outside of the Sterling Area, sterling was inconvertible into hard currencies or gold.

34. Various drafts of the Keynes and White plans are reproduced in Horsefield (1969). The French and the Canadians also advanced proposals (the latter was known colloquially as the "off-White" plan).

35. There were, of course, numerous dissenters from various aspects of this consensus, for example Friedman (1953), who argued for floating exchanges and freedom of short-term capital movements, and Viner (1943a), who espoused fixed rates but believed they might be consistent with a liberal capital transfer regime. Some still argued for the gold standard (see the New York Times, March 30, 1943).

36. Harrod (1951, pp. 525-6) ascribes the shift to Keynes's perception in 1941 that in a new postwar order, Keynesian economics might be applied on a global scale, rather than the national scale he envisaged in the 1930s.

37. In Keynes's conception, central banks would be monopoly dealers in foreign exchange within each country; they in turn would sell foreign exchange to the ICU for bancor credits, or settle directly with foreign central banks. 
As monopoly dealers, the central banks were ideally placed to scrutinize all foreign exchange transactions and deny foreign exchange for purposes of capital transfer (Keynes 1980a, p. 216).

38. The draft is dated February 11, 1942.

39. In 1956 the IMF's Executive Directors interpreted Article VI as allowing countries (subject to some mild restrictions) to impose capital controls "for any reason" and "without approval of the Fund" (Horsefield 1969, p. 246).

40. The evolution of White's political views is discussed by Rees (1973).

41. See Yeager (1976, pp. 409-10), for further discussion of this "contagion of bilateralism." See also Triffin (1957, pp. 88-93). The basic mechanisms at work were emphasized by Viner (1943b).

42. See Kaplan and Schleiminger (1989, p. 57) and Yeager (1976, p. 409).

43. Canada added $\$ 1.25$ billion to the loan.

44. See Wyplosz (1986) for a formal analysis of speculative attacks under capital controls.

45. For discussions of the EPU, see Triffin (1957), Kaplan and Schleiminger (1989), and Eichengreen (1993).

46. On Germany's attempts to counteract the inflationary potential of its balanceof-payments surpluses, see Boarman (1964) and Emminger (1977). Germany's relatively fast productivity growth in the $1950 \mathrm{~s}$ and $1960 \mathrm{~s}$ mandated a secular real appreciation of the Deutsche mark against the dollar, that is, a rise in Germany's price level measured in dollars against that of the United States. Given a fixed nominal exchange rate, however, this equilibrating real currency appreciation could occur only through higher inflation in Germany than in the America - something German policymakers were largely unwilling to accept. This tension made revaluation inevitable once German capital markets were fully open. In contrast, Japan did accept a higher inflation rate than that of the United States (Obstfeld 1993).

47. Concern about the U.S. balance of payments deficit was not universal. For a cogent contrary position, see Kindleberger (1965). For some skeptical remarks on the importance of the "confidence problem" posed by an increasing ratio of official dollar liabilities to U.S. gold, see Obstfeld (1993, p. 211).

48. Edwards (1995, chap. 3) analyzes the forces behind the recent trend of economic liberalization in Latin America. 


\section{References}

Alesina, Alberto, Grilli, Vittorio, and Milesi-Ferretti, Gian Maria. 1994. The Political Economy of Capital Controls. In Capital Mobility: The Impact on Consumption, Investment and Growth, edited by Leonardo Leiderman and Assaf Razin. Cambridge: Cambridge University Press.

Bakker, Age F. P. 1996. The Liberalization of Capital Movements in Europe: The Monetary Committee and Financial Integration, 1958-1994. Dordrecht: Kluwer.

Bernanke, Ben S. 1995. The Macroeconomics of the Great Depression: A Comparative Approach. Journal of Money, Credit, and Banking 27 (February): 1-29.

Bernanke, Ben S., and Kevin Carey. 1996. Nominal Wage Stickiness and Aggregate Supply in the Great Depression. Quarterly Journal of Economics 111 (August): 853-83.

Black, Stanley W. 1991. A Levite among the Priests: Edward M. Bernstein and the Origins of the Bretton Woods System. Boulder, Colo.: Westview Press.

Boarman, Patrick M. 1964. Germany's Economic Dilemma: Inflation and the Balance of Payments. New Haven, Conn.: Yale University Press

Bordo, Michael David. 1993. The Bretton Woods International Monetary System: A Historical Overview. In A Retrospective on the Bretton Woods System: Lessons for International Monetary Reform, edited by Michael David Bordo and Barry J. Eichengreen. Chicago: University of Chicago Press.

Bordo, Michael David, and Finn E. Kydland. 1995. The Gold Standard as a Rule: An Essay in Exploration. Explorations in Economic History 32: 42364.

Bordo, Michael David, and Hugh Rockoff. 1996. The Gold Standard as a 'Good Housekeeping Seal of Approval.' Journal of Economic History 56 (June): 389-428.

Bratter, H. M. 1939. Foreign Exchange Control in Latin America. Foreign Policy Reports $14: 274-88$.

Brown, William Adams, Jr, 1940. The International Gold Standard Reinterpreted, 1914-1934. 2 vols. New York: National Bureau of Economic Research.

Cairncross, Alec 1985. Years of Recovery: British Economic Policy 1945-51. London: Methuen.

Campa, José M. 1990. Exchange Rates and Economic Recovery in the 1930s: An Extension to Latin America. Journal of Economic History 50 (September): 677-82. 
Capie, Forrest, and Alan Webber. 1985. A Monetary History of the United Kingdom, 1870-1982. London: George Allen \& Unwin.

Choudhri, Ehsan U., and Levis A. Kochin. 1980. The Exchange Rate and the International Transmission of Business Cycle Disturbances: Some Evidence from the Great Depression. Journal of Money, Credit and Banking 12 (November): 565-74.

Dam, Kenneth W. 1982. The Rules of the Game: Reform and Evolution in the International Monetary System. Chicago: University of Chicago Press.

Davis, Lance E., and Robert J. Cull. 1994. International Capital Markets and American Economic Growth, 1820-1914. Cambridge: Cambridge University Press.

Deutsche Bundesbank. 1959. Foreign Trade and the Balance of Payments. Monthly Report of the Deutsche Bundesbank 11 (January): 43-52.

Díaz Alejandro, Carlos F. 1983. Stories of the 1930s for the 1980s. In Financial Policies and the World Capital Market: The Problem of Latin American Countries, edited by Pedro Aspe, Rudiger Dornbusch, and Maurice Obstfeld. Chicago: University of Chicago Press.

Diaz Alejandro, Carlos F. 1984. Latin America in the 1930s. In Latin America in the 1930s: The Role of the Periphery in World Crisis, edited by Rosemary Thorp. New York: St. Martin's Press.

Edelstein, Michael. 1982. Overseas Investment in the Age of High Imperialism. New York: Columbia University Press.

Edwards, Sebastian. 1995. Crisis and Reform in Latin America: From Despair to Hope. Oxford: Oxford University Press.

Eichengreen, Barry J. 1991. The Comparative Performance of Fixed and Flexible Exchange Rate Regimes: Interwar Evidence. In Business Cycles: Theory, Evidence and Analysis, edited by Niels Thygesen, Kumaraswamy Velupillai, and Stefano Zambelli. New York: New York University Press.

Eichengreen, Barry J. 1992a. Trends and Cycles in Foreign Lending. In Capital Flows in the World Economy, edited by Horst Siebert. Tübingen: J. C. B. Mohr.

Eichengreen, Barry J. 1992b. Golden Fetters: The Gold Standard and The Great Depression, 1919-1939. Oxford: Oxford University Press.

Eichengreen, Barry J. 1993. Reconstructing Europe's Trade and Payments: The European Payments Union. Ann Arbor: University of Michigan Press.

Eichengreen, Barry J., and Jeffrey D. Sachs. 1985. Exchange Rates and Economic 
Recovery in the 1930s. Journal of Economic History 45 (Deccmber): 925-46.

Einzig, Paul. 1934. Exchange Control. London: Macmillan.

Einzig, Paul. 1937. The Theory of Forward Exchange. London: Macmillan.

Einzig, Paul. 1968. Leads and Lags: The Main Cause of Devaluation. London: Macmillan.

Ellis, Howard S. 1941. Exchange Control in Central Europe. Cambridge: Harvard University Press.

Emminger, Otmar 1977. The D-Mark in the Conflict between Internal and External Equilibrium, 1948--75. Princeton Essays in International Finance 122.

Epstein, Gerald A., and Juliet B. Schor. 1992. Structural Determinants and Economic Effects of Capital Controls in OECD Countries. In Financial Openness and National Autonomy, edited by Tariq Banuri and Juliet B. Schor. Oxford: Clarendon Press.

Feldstein, Martin, and Charles Horioka. 1980. Domestic Savings and International Capital Flows. Economic Journal 90 (June): 31429.

Fishlow, Albert. 1971. Origins and Consequences of Import Substitution in Brazil. In International Economics and Development: Essays in Honor of Raúl Prebisch, edited by Luis Eugenio Di Marco. New York: Academic Press.

Folkerts-Landau, David, and Takatoshi Ito, with others. 1995. International Capital Markets: Developments, Prospects, and Policy Issues. Washington, D.C.: International Monetary Fund.

Frankel, Jeffrey A. 1984. The Yen/Dollar Agreement: Liberalizing Japanese Capital Markets. Washington, D.C.: Institute for International Economics.

Friedman, Milton. 1953. The Case for Flexible Exchange Rates. In Essays in Positive Economics. Chicago: University of Chicago Press.

Gardner, Richard N. 1980. Sterling-Dollar Diplomacy in Current Perspective. New York: Columbia University Press.

Giavazzi, Francesco, and Alberto Giovannini. 1989. Limiting Exchange Rate Flexibility: The European Monetary System. Cambridge: MIT Press.

Giovannini, Alberto. 1993. Bretton Woods and Its Precursors: Rules versus Discretion in the History of International Monetary Regimes. In A Retrospective on the Bretton Woods System: Lessons for International Monetary Reform, edited by Michael David Bordo and Barry J. Eichengreen. Chicago: University of Chicago Press. 
Gordon, Margaret S. 1941. Barriers to World Trade. New York: Macmillan.

Goschen, G. J. 1861. The Theory of the Foreign Exchanges. London: Effingham Wilson.

Grilli, Vittorio, and Gian Maria Milesi-Ferretti. 1995. Economic Effects and Structural Determinants of Capital Controls. IMF Staff Papers 42 (September): $517-51$.

Haberler, Gottfried. 1976. The World Economy, Money, and the Great Depression 1919-1939. Foreign Affairs Study 30. Washington, D.C.: American Enterprise Institute.

Hallwood, C. Paul, Ronald MacDonald, and Ian W. Marsh. 1996. Credibility and Fundamentals: Were the Classical and Interwar Gold Standards Well-Behaved Target Zones? In Modern Perspectives on the Gold Standard, edited by Tamim Bayoumi, Barry J. Eichengreen, and Mark P. Taylor. Cambridge: Cambridge University Press.

Hamilton, James D. 1988. The Role of the International Gold Standard in Propagating the Great Depression. Contemporary Policy Issues 6: 67-89.

Harrod, Roy F. 1951. The Life of John Maynard Keynes. London: Macmillan.

Helleiner, Eric. 1994. States and the Reemergence of Global Finance: iFrom Bretton Woods to the 1990s. Ithaca: Cornell University Press.

Horsefield, J. Keith, ed. 1969. The International Monetary Fund 1945-1965, vol. 3. Washington, D.C.: International Monetary Fund.

Ito, Takatoshi. 1992. The Japanese Economy. Cambridge: MIT Press.

Kaplan, Jacob J., and Günther Schleiminger. 1989. The European Payments Union: Financial Diplomacy in the 1950s. Oxford: Clarendon Press.

Kapstein, Ethan B. 1994. Governing the Global Economy: International Finance and the State. Cambridge: Harvard University Press.

Keynes, John Maynard. 1978. Activities 1939-1945: Internal War Finance. The Collected Writings of John Maynard Keynes, vol. 22, edited by Donald Moggridge. London: Macmillan.

Keynes, John Maynard. 1980a. Activities 1940-1944: Shaping the Post-War World: The Clearing Union. The Collected Writings of John Maynard Keynes, vol. 25, edited by Donald Moggridge. London: Macmillan.

Keynes, John Maynard. 1980b. Activities 1941-1946: Shaping the Post-War World: Bretton Woods and Reparations. The Collected Writings of John Maynard 
Keynes, vol. 26, edited by Donald Moggridge. London: Macmillan.

Keynes, John Maynard. 1982. Activities 1931-1939: World Crises and Policies in Britain and America. The Collected Writings of John Maynard Keynes, vol. 21, edited by Donald Moggridge. London: Macmillan.

Kindleberger, Charles P. 1965. Balance-of-Payments Deficits and the International Market for Liquidity. Princeton Essays in International Finance 46.

Kindleberger, Charles P. 1984. A Financial History of Western Europe. London: George Allen \& Unwin.

Kindleberger, Charles P. 1986. The World in Depression, 1929-1939. Revised edition. Berkeley and Los Angeles: University of California Press.

League of Nations. 1938. Report on Exchange Control. Geneva: League of Nations.

Lewis, Karen K. 1996. Puzzles in International Financial Markets. In Handbook of International Economics, vol. 3, edited by Gene M. Grossman and Kenneth Rogoff. Amsterdam: Elsevier.

Lothian, James R. 1995. Capital Market Integration and Exchange-Rate Regimes in Historical Perspective. Manuscript. New York: Fordham University (December).

Lucas, Robert E., Jr. 1990. Why Doesn't Capital Flow from Rich to Poor Countries? American Economic Review 80 (May): 92-6.

McKinnon, Ronald I. 1979. Money in International Exchange: The Convertible Currency System. New York: Oxford University Press.

Marston, Richard C. 1995. International Financial Integration. Cambridge: Cambridge University Press.

Mikesell, Raymond F. 1954. Foreign Exchange in the Postwar World. New York: Twentieth Century Fund.

Moggridge, D. E. 1971. British Controls on Long Term Capital Movements, 19241931. In Essays on a Mature Economy: Britain after 1840, edited by Donald N. McCloskey. London: Methuen.

Morgenstern, Oskar. 1959. International Financial Transactions and Business Cycles. Princeton, N.J.: Princeton University Press.

Nurkse, Ragnar (with William Adams Brown, Jr.). 1944. International Currency Experience: Lessons of the Inter-war Period. Geneva: League of Nations. 
Obstfeld, Maurice. 1993. The Adjustment Mechanism. In A Retrospective on the Bretton Woods System: Lessons for International Monetary Reform, edited by Michael David Bordo and Barry J. Eichengreen. Chicago: University of Chicago Press.

Obstfeld, Maurice. 1995. International Capital Mobility in the 1990s. In Understanding Interdependence: The Macroeconomics of the Open Economy, edited by Peter B. Kenen. Princeton, N.J.: Princeton University Press.

Obstfeld, Maurice, and Kenneth Rogoff. 1996. Foundations of International Macroeconomics. Cambridge: MIT Press.

Officer, Lawrence H. 1996. Between the Dollar-Sterling Gold Points: Exchange Rates, Parity, and Market Behavior. Cambridge: Cambridge University Press.

Perkins, Edwin J. 1978. Foreign Interest Rates in American Financial Markets: A Revised Series of Dollar-Sterling Exchange Rates, 1835-1900. Journal of Economic History 38 (June): 392-417.

Rees, David. 1973. Harry Dexter White: A Study in Paradox. New York: Coward, McCann \& Geoghegan.

Sachs, Jeffrey D., and Andrew Warner. 1995. Economic Reform and the Process of Global Integration. Brookings Papers on Economic Activity 1: 1-118.

Salera, Virgil. 1941. Exchange Control and the Argentine Market. New York: Columbia University Press.

Sayers, R. S. 1976. The Bank of England 1891-1944. Cambridge: Cambridge University Press.

Solomon, Robert. 1982. The International Monetary System, 1945-1981. New York: Harper \& Row.

Spalding, William F. 1915. Foreign Exchange and Foreign Bills in Theory and in Practice. London: Sir Isaac Pitman \& Sons.

Stewart, Robert B. 1938. Great Britain's Foreign Loan Policy. Economica 5 N. S. (February): 45-60.

Svensson. Lars E. O. 1991. The Simplest Test of Target Zone Credibility. International Monetary Fund Staff Papers 38 (September): 655-65.

Taylor, Alan M. 1996a. International Capital Mobility in History: Purchasing Power Parity in the Long-Run. Working Paper Series no. 5742, National Bureau of Economic Research (August).

Taylor, Alan M. 1996b. International Capital Mobility in History: The Saving- 
Investment Relationship. Working Paper Series no. 5743, National Bureau of Economic Research (August).

Temin, Peter. 1989. Lessons from the Great Depression. Cambridge: MIT Press.

Triffin, Robert. 1957. Europe and the Money Muddle: From Bilateralism to NearConvertibility, 1947-1956. New Haven, Conn.: Yale University Press.

Viner, Jacob. 1943a. Two Plans for International Monetary Stabilization. Yale Review 23: 77-107.

Viner, Jacob. 1943b. Trade Relations between Free-Market and Controlled Economies. Geneva: League of Nations.

Weill, N. E. 1903. Die Solidarität der Geldmärkte. Frankfurt: J. D. Sauerländer's Verlag.

Williamson, Jeffrey G. 1996. Globalization, Convergence, and History. Journal of Economic History 56 (June): 277-306.

Wood, Adrian. 1994. North-South Trade, Employment, and Inequality: Changing Fortunes in a Skill-Driven World. Oxford: Clarendon Press.

Wyplosz, Charles. 1986. Capital Controls and Balance of Payments Crises. Journal of International Money and Finance 5 (June): 167-79.

Yeager, Leland B. 1976. International Monetary Relations: Theory, History, and Policy. 2d edition. New York: Harper \& Row. 